\title{
THE HISTORICAL DEVELOPMENT OF DIAMOND MINING LEGISLATION IN GRIQUALAND WEST DURING THE PERIOD 1871 TO 1880
}

\author{
Anneke Higgs*
}

\section{ABSTRACT}

In 1871 the diamond fields where the first known diamonds in South Africa were discovered were proclaimed as a British territory named Griqualand West. In 1880 Griqualand West was annexed as part of the Cape Colony. During the period 1871 to 1880 , Griqualand West was under the control of three different administrations, each of which enacted different diamond mining legislation. This article provides a historical overview of the diamond mining legislation that was enacted in Griqualand West from 1871 to 1880 in order to determine the factors which influenced the development of diamond mining legislation in Griqualand West.

Keywords: Diamond mining legislation; Griqualand West; mining; prospecting; diamonds; land tenure

\section{Introduction}

The discovery of diamonds in South Africa played an important part in the development of the country's economy. The Eureka diamond, which is acknowledged to be the

* Member of the Pretoria Bar. The article is based on a LLD thesis completed at the North-West University in 2017 with the title "The historical development of the right to mine diamonds in South Africa". 
first diamond discovered in South Africa, was discovered in 1866 in the district of Hopetown, an area which was then regarded as "no-man's land". It was, following the discovery of diamonds, simply referred to as the diamond fields ${ }^{1}$ and in 1871 it was proclaimed as British territory.

The period after the proclamation of Griqualand West as a British territory in 1871 may - from a diamond mining perspective - be divided into three periods. First, the period between 1871 and 1872 during which Griqualand West was under the control of Sir Barkly as Governor, and administered by three Commissioners. Second, the period from 1873 until 1879 when Griqualand West was designated a province and became a British Crown Colony, ${ }^{2}$ and, third, the period after the annexation of Griqualand West as part of the Cape Colony in 1880. During each of these periods, different legislative measures were adopted to regulate the search for diamonds and the working of claims in Griqualand West. In this article, the historical development of the diamond mining legislation that was enacted in Griqualand West from 1871 until the annexation thereof as part of the Cape Colony in 1880 is analysed.

\section{First period: The three Commissioners during 1871 and 1872}

After the proclamation of Griqualand West as a British territory, Sir Barkly governed Griqualand West from Cape Town, the capital of the Cape Colony. ${ }^{3}$ In 1871 Griqualand West was divided into three magisterial districts, namely Klipdrift, Pniel and Griqua Town. ${ }^{4}$ Sir Barkly appointed three Commissioners to administer Griqualand West on his behalf, one for each of the three districts. ${ }^{5}$

During the two years that Sir Barkly governed Griqualand West through the three Commissioners, approximately seventy-four proclamations were passed. Three of these proclamations were important from a diamond mining perspective. In the

$1 \quad$ Herbert 1972: 11; Boyle 1873: 84; Roberts 1984: 5; Beet \& Terpend 1917: 15-18; Williams 1905: 115; McNish 1968: 15-17; Davenport 2013: 40; Worger 1987: 9; Marquard 1955: 178; Minister of Mineral Resources of the Republic of South Africa v Sishen Iron Ore Company (Pty) Ltd 2013 (4) SA 461 (SCA) par 3; Simons 2004: 10-11; Rotberg 2002: 57; Roberts 1972: 4; Doughty 1963: 202; Machens 2009: 139-142; Hornsby 1874: 5; Millin 1933: 10.

2 During this period, Griqualand West was under the control of Lieutenant-General Southey, who was dismissed in 1875 and replaced by Major William Owen in 1875 as Administrator. See Buchanan 1882: par 6.

3 Sir Barkly issued seven proclamations in respect of Griqualand West on 27 Oct 1871. In Griqualand West Procl 68 of 27 Oct 1871, he proclaimed that the laws and "usages" of the Cape Colony were deemed to be the laws of Griqualand West insofar as the laws were not inapplicable. In Griqualand West Procl 70 of 1871, provision was made for a High Court of Griqualand West pending the passing of a law to provide for the annexation of Griqualand West as part of the Cape Colony.

4 Griqualand West Procl 69 of 27 Oct 1871.

$5 \quad$ Griqualand West Procl 73 of 27 Oct 1871; Buchanan 1882: par 5. 
first proclamation, namely the Griqualand West Proclamation 71 of 27 October 1871 (hereafter the $1871 \mathrm{GW}$ Diggings Proclamation), provision was made for rules and regulations under which the search for diamonds or digging of claims in Griqualand West had to be carried out. ${ }^{6}$ In the second proclamation, the Griqualand West Proclamation 72 of 1871, which was also passed on 27 October 1871, provision was made for the acknowledgement of existing private rights or titles to possess movable or immovable property which had been bona fide acquired by the inhabitants of Griqualand West. This proclamation became known as the "Quieting Proclamation" (hereafter the $1871 \mathrm{GW}$ Quieting Proclamation). And in the third proclamation, the Griqualand West Proclamation 59 of 7 November 1872 (hereafter the 1872 GW Prospecting Proclamation) provision was made for regulations for the payment of licences for prospecting on private property.

Each of these three proclamations impacted on the development of the right to mine diamonds in Griqualand West and they are discussed in the following subsections.

\section{The 1871 Griqualand West Diggings Proclamation}

The 1871 GW Diggings Proclamation was adopted to regulate the working of claims to extract diamonds once a diamond field had been proclaimed. Its purpose was thus to regulate the working of claims after the diamonds had already been discovered and a diamond field proclaimed. The prospecting or searching for diamonds was not regulated under the 1871 GW Diggings Proclamation. The 1871 GW Diggings Proclamation referred to the "searching" for diamonds in the context of the working or digging of claims in proclaimed diamond fields.

\section{The working of claims}

Each diamond field proclaimed under the $1871 \mathrm{GW}$ Diggings Proclamation was divided into different claims. ${ }^{7}$ Every person who wanted to work a claim had to obtain a digging licence.

There was no statutory reservation of the rights to diamonds in favour of the British Crown or the Government of the Cape Colony during the period that

6 Buchanan 1882: pars 5-6, states that initially no Government Gazette existed in Griqualand West. The early proclamations seemed to have been promulgated by the Commissioners themselves reading them out in the presence of the diggers at the various diamond fields.

7 Section 19 of the 1871 GW Diggings Proclamation provided that the size of each claim was thirty feet by thirty feet or nine hundred square feet. In terms of s 5 of the $1871 \mathrm{GW}$ Diggings Proclamation an Inspector was appointed for each diamond field with duties and powers as set out in the $1871 \mathrm{GW}$ Diggings Proclamation. The Inspector of each proclaimed diamond field had to mark out, with pegs, the boundaries of the different claims in the diamond fields. In terms of ss 2-5 of the $1871 \mathrm{GW}$ Diggings Proclamation the Inspector was obliged to keep a register of claims within the relevant diamond field and to receive licence money or royalty or rent payable for the right to search for or to dig diamonds within the relevant diamond field. 
Griqualand West was administered by the three Commissioners. The question as to who was entitled to work claims (where diamonds had already been discovered) depended on the specific form of land tenure.

Three types of land tenure were acknowledged in the $1871 \mathrm{GW}$ Diggings Proclamation. These three forms were, first, Crown land; second, private land and the title of which was subject to the reservation of rights to diamonds, presumably in favour of the British Crown (hereafter in this article referred to as reserved private land) $;{ }^{8}$ and third, private land without any such reservation in the title deed of the land (hereafter in this article referred to as unreserved private land). The $1871 \mathrm{GW}$ Diggings Proclamation did not provide definitions for these different types of land tenure.

In the case of the discovery of diamonds on Crown land or reserved private land, the High Commissioner was entitled to proclaim, by public advertisement, a diamond field on the Crown land or reserved private land. In the case of the proclamation of a diamond field on reserved private land, the consent of the relevant landowner was not required for the proclamation of a diamond field, although certain measures were adopted in an attempt to accommodate the landowner. ${ }^{9}$ In the case of Crown land and reserved private land, the Crown could, by granting digging licences to members of the public, determine and regulate who was entitled to dig for diamonds.

In the case of the discovery of diamonds on unreserved private land, the consent of the landowner was required before a diamond field could be proclaimed. ${ }^{10}$ Section 29 of the $1871 \mathrm{GW}$ Diggings Proclamation provided that a digging situated on unreserved private land was deemed to be a public diamond field, which could be proclaimed as such, provided firstly, that the landowner consented to the establishment of diamond diggings on his property and, secondly, that the landowner granted at least twenty-four claim licences to work claims on his land, or he must have granted licences to search for diamonds on his land on a total surface of at least 20000 square feet. ${ }^{11}$

Every claimholder had to pay a royalty or rent. In the case of Crown land and reserved private land the sum of licence monies, royalties or rent that the holder of a digging licence had to pay, was prescribed. ${ }^{12}$ In the case of unreserved private land,

8 Section 23 of the 1871 GW Diggings Proclamation states as follows: "The private property of any person, the title to which lands (sic) is or shall be subject in the original grant thereof to a reservation of the right to precious stones or minerals." It is not the purpose of this article to analyse or address the concept of "land tenure" or its origin. In this article the term "land tenure" is used with reference to land rights.

9 Sections 1 and 23 of the 1871 GW Diggings Proclamation provided that a diamond field could be proclaimed in respect of existing diggings and new diggings.

10 Idem at $\mathrm{s} 29$.

11 Ibid.

12 Section 20 of the $1871 \mathrm{GW}$ Diggings Proclamation provided that with regard to claims that were worked by no more than three people, an amount of five shillings per month was payable. Where a claim was worked by not more than six persons, an amount of ten shillings per month was payable. Thereafter, for every additional person employed by the claimholder, an amount of two shillings per month was payable. 
the landowner had to determine the licence money, rent or royalty payable for each claim. The Civil Commissioner had to collect the monthly payments to be made by the diggers in respect of diamond fields proclaimed on unreserved private land and account to the relevant landholder, withholding one-tenth of the money recovered and any costs incurred for the establishment and maintenance of the land on which the diamond field was situated. ${ }^{13}$ The diggers at each digging could establish a Diggers' Committee which could adapt rules or by-laws which had to be adopted at a public meeting called by the Inspector. The rules or by-laws, including those rules and by-laws that had previously been adopted in respect of existing diggings, had to be sent to the Civil Commissioner for approval. ${ }^{14}$ There was no provision in the 1871 GW Diggings Proclamation prescribing the number of claims that each claimholder could hold. ${ }^{15}$

Claimholders could transfer their claims provided that the Inspector had registered the transfer of the claims and that all licence money, royalty or rent and registration fees due and payable had been paid in respect of the relevant claim. ${ }^{16}$ The so-called "jumping" system that previously applied at the river diggings was continued. This system provided that diggers had to work their claims continuously, which assisted in the uniform working of a pit. ${ }^{17}$ If a person failed bona fide to work a claim for eight days, his claim was forfeited. ${ }^{18}$

13 Section 29 of the 1871 GW Diggings Proclamation. Later, the maximum amount which a landowner could charge in terms of the $1872 \mathrm{GW}$ Prospecting Proclamation was fixed at one pound per month.

14 Section 14 of the $1871 \mathrm{GW}$ Diggings Proclamation. Rules or by-laws that were in conflict with substantial justice and reason or with any of the provisions in the $1871 \mathrm{GW}$ Diggings Proclamation could - in terms of s 15 of the 1871 GW Diggings Proclamation - not be approved. The interests of landowners of reserved private land were, in terms of s 23 of the $1871 \mathrm{GW}$ Diggings Proclamation, protected in that no rules or by-laws passed at any public meeting, which limited the amount of compensation payable to the landowner, were valid unless the relevant landowner consented thereto. Landowners of unreserved land were similarly protected in that s 29 of the 1871 GW Diggings Proclamation provided that no rules or by-laws that were passed at a public meeting, affecting or interfering with the landowner's property rights or defining the compensation to be paid were binding on any landowner without his consent.

15 According to Worger 1987: 16-17, the diggers could only hold two claims pursuant to the 1871 GW Mining Proclamation. See, also, Davenport 2009: 52. No support for these statements could be found in the $1871 \mathrm{GW}$ Diggings Proclamation.

16 Sections 7 and 8 of the 1871 GW Diggings Proclamation. The Inspector was required to register every purchase or transfer of every claim in respect of the relevant diamond field. Every vendor or purchaser had to pay a registration fee of five shillings upon the registration of each purchase.

17 See Turrell 1987: 34-35.

18 Section 16 of the 1871 GW Diggings Proclamation. Section 16 of the 1871 GW Diggings Proclamation was later suspended. According to Davenport 2009: 52, the $1871 \mathrm{GW}$ Diggings Proclamation prevented the monopolisation of the diamond industry through the continued application of the "jumping system". 


\section{The interests of the landowner}

Although a diamond field could be proclaimed on reserved private land without the consent of the landowner, certain measures were included in the $1871 \mathrm{GW}$ Diggings Proclamation to protect the interests of the landowner. The High Commissioner first had to attempt to reach an agreement with the landowner of the reserved private land on the terms and conditions on which diamond diggings on the reserved private land could be worked or the terms on which diggers could search for diamonds on the reserved private land. If they could not reach an agreement, the High Commissioner could simply enter the reserved private land or cause such land to be entered in order to take possession of the mines and the diamonds therein on behalf of the British Crown, provided that notice of the entry was given to the landowner. ${ }^{19}$ The landowner was entitled to reasonable compensation for all damage caused to the surface and soil of the land as a result of the diamond digging, mining and the searching for diamonds on his land. The amount that was payable for any damage to the surface and soil of the reserved private land had to be agreed on between the landowner and the High Commissioner within a period of three months. ${ }^{20}$ The landowner could also, instead of accepting compensation for damages, agree to sell his property to the High Commissioner. ${ }^{21}$

\section{The 1871 GW Quieting Proclamation}

Although the $1871 \mathrm{GW}$ Quieting Proclamation did not specifically refer to diamonds, it impacted on the searching for diamonds and the working of diamond diggings in Griqualand West. ${ }^{22}$ In the $1871 \mathrm{GW}$ Quieting Proclamation Sir Barkly declared that existing private rights or titles to possess any movable or immovable property which had been bona fide acquired by inhabitants of Griqualand West under the laws of the State and Government under which they were previously living de facto, would not be invalidated or prejudicially affected..$^{23}$

19 See Union Government (Minister of Mines) v Thompson 1919 AD 404 at 421.

20 Section 26 of the 1871 GW Diggings Proclamation provided that if they could not reach an agreement within three months, the dispute had to be referred to arbitration to determine the amount payable.

21 If the parties could not agree on the purchase price within three months, the dispute was in terms of s 28 of the $1871 \mathrm{GW}$ Diggings Proclamation also referred to arbitration. The value of the diamonds existing on or under the land could in terms of ss 27 and 28 of the 1871 GW Diggings Proclamation not be taken into account in determining the compensation payable for the purchase price of the land.

22 See Webb v Giddy 18783 App Cas 908.

23 Dale 1979: 353. It was recorded in the preamble of the 1871 GW Quieting Proclamation that the inhabitants of the Griqualand territory may have had doubts in particular regarding the status of land that they occupied, the sovereignty over which there had previously been a dispute between the Griqua Chief, Waterboer and the Governments of the Orange Free State and the ZuidAfrikaansche Republiek. The Appellate Division held in Botha v Minister of Lands 1965 (1) SA 728 (A) that the object of the $1871 \mathrm{GW}$ Quieting Proclamation, was "to quiet the apprehension of inhabitants of the new British Territory with regard to the existing titles to their land, "especially those occupying lands' which had been affected by the Keate Award". 
All persons that claimed any title or right of possession or any other right in land within Griqualand West, were requested to submit a written statement to the Civil Commissioner of the district in which such land was situated, setting out details of the claim and the nature of the rights claimed. The details of the rights and titles had to be recorded publicly. ${ }^{24}$ The $1871 \mathrm{GW}$ Quieting Proclamation further provided that the existing titles of private persons would be duly respected and considered to be valid if they would have been valid under the laws of the de facto Government under which the private persons holding them were previously living. ${ }^{25}$

The real impact of the 1871 GW Quieting Proclamation only became clear a few years later. A special Land Court was established in Griqualand West through the Griqualand West Ordinance 3 of 1875 dated 9 September $1875^{26}$ to adjudicate on land claims in Griqualand West, which then had the status of a province. Judgments or decrees of the Land Court were provisional for a period of three months to provide aggrieved parties with an opportunity to appeal to the High Court of Griqualand West. After the lapsing of the period of three months, application could be made to the Land Court to obtain a final judgment if an appeal had not been noted. ${ }^{27}$ Any person who obtained a final order would be entitled to demand and receive a title from the Governor with regard to the land that formed the object of the judgment in accordance with the terms of the judgment..$^{28}$

24 Section 1 of the 1871 GW Quieting Proclamation.

25 See s 2 of the 1871 GW Quieting Proclamation. The confirmation or the cancellation of titles claimed by grant or other document from the Government of the Orange Free State or the Government of the Zuid-Afrikaansche Republiek in Griqualand West after 1 Jan 1870 was specifically reserved. Section 3 of the $1871 \mathrm{GW}$ Quieting Proclamation provided that each case would be investigated by Sir Barkly and that the relevant title deed would either be cancelled or confirmed or confirmed subject to certain conditions.

26 The title of which was "Ord to Establish a Court to Adjudicate on Claims to Land in the Province of Griqualand West" (hereafter the 1875 GW Land Court Ord). See, also, Buchanan 1882: par 25.

27 This requirement was dispensed with in 1876 with the adoption of the Amendment of Land Court Ord 13 of 1876 of 13 Oct 1876 which provided that a provisional judgment granted by the Land Court became final upon the expiration of three months in every case where an appeal was not noted within the three-month period.

28 See s 10 of the 1875 GW Land Court Ord. In London and SA Exploration Co Ltd $v$ Kimberley Divisional Council 18843 HCG 125, the landowners of the farm Alexanderfontein, situated in the Kimberley district, instituted an action against the Kimberley Divisional Council for trespassing on their farm. The plaintiffs argued that they owned the farm Alexanderfontein by virtue of a grant from the Government of the Orange Free State. The Kimberley Divisional Council erected a tollhouse and other buildings on the farm and pleaded that with effect from the date of proclamation of the $1871 \mathrm{GW}$ Proclamation on 27 Oct 1871 (providing for the proclamation of Griqualand West as a British Territory) the farm Alexanderfontein vested in the British Crown. The farm Alexanderfontein had originally been granted to its first owners by the Government of the Orange Free State in 1862 on perpetual quitrent, subject to certain conditions which were registered against the title of the land, including the following: "That all roads passing over this land, or which may hereafter be made upon lawful authority, shall remain free and unencumbered ... that the said land shall be further subject to all such duties and regulations as already are or may in future be established concerning lands granted upon the like condition." The farm Alexanderfontein was included in the area that was proclaimed as a British territory known as Griqualand West in 1871. In 1876, the London and South African Exploration Company Limited's title was confirmed by the Land Court of Griqualand West. No new title was issued to the owners of the farm. The High Court of Griqualand West held that it was clear from the $1871 \mathrm{GW}$ Quieting Proclamation that the effect of $1871 \mathrm{GW}$ Proclamation was not to transfer the dominium in the farm Alexanderfontein to 
In Carter v Van Niekerk and Union Government (Minister of Lands) ${ }^{29}$ the landowner of a farm riparian to the Vaal River instituted an action against Van Niekerk, a digger (operating under a digger licence) who had dug for and extracted diamonds from the half of the river bed adjoining the owner's farm, which the owner argued formed part of his land. In 1863 the then President of the Orange Free State granted the farm in question to Carter's predecessors in title. The predecessors in title applied to the Land Court in terms of the $1875 \mathrm{GW}$ Land Court Ordinance and obtained judgment on 19 June 1876 in which it was confirmed that the law of the Orange Free State applied to the land. ${ }^{30}$ The previous owners who obtained judgment in the Land Court did nothing further with regard to the judgment. Approximately four years later on 15 July 1880 the Governor, without waiting for a demand or request from the landowners, proceeded to issue and register a title in respect of the land. The following condition was included in the title deed of 15 July 1880:

That the issue of this title without any express reservation to the Government of its rights to all precious stones, gold or silver found on or under the surface of the land shall in no degree prejudice the position of the said Government in regard to the same.

Chief Justice Maasdorp remarked that the title was issued in the form of a new and original grant in perpetual quitrent without the reservation to the landowners of their rights under their "Free State title" or under the judgment of the Land Court and with the addition of the clause regarding the reservation of precious stones which did not form part of their original title or the judgment. ${ }^{31}$ The landowner argued that as the owner of the land he was also the owner of all diamonds, gold and silver on

the British Crown, but to acknowledge and confirm the rights of persons that claimed any title or right of possession in movable or immovable property. The Court held further that the farm was held under a title from the Government of the Orange Free State, without the conditions in favour of the British Crown reserved in Colonial quitrent titles which existed under Sir John Cradock's Proclamation on Conversion of Loan Places to Quitrent Tenure 6 of 1813 (hereafter the Cradock Proclamation). The Kimberley Divisional Council therefore had no right to enter the plaintiff's land and to erect the toll-house and buildings thereon. The Court concluded that the plaintiff was protected by the Orange Free State title against the invasions of their proprietary rights which rights had to be protected as provided for in the 1871 GW Quieting Proclamation. On appeal, the Kimberley Divisional Council argued that the Cradock Proclamation became applicable to the farm Alexanderfontein by operation of law when Griqualand West was annexed to the Cape Colony in 1880. In Kimberley Divisional Council v London and SA Exploration Co Ltd 188519062 Buch AC 84, Chief Justice De Villiers dismissed the appeal and held that s 4 of the Cradock Proclamation did not apply to quitrent land in the Cape Colony unless the grant of the land contained such a reservation.

29 1910-1917 GWLD 445.

30 Chief Justice Maasdorp recorded at 459 that " $[t]$ he reasons which influenced the Judge of the Land Court in giving his judgment in favour of the claimants of farms under Free State titles were put in the course of the evidence of the witness ... and are to the following effect ... I must hold, under Ord 72, 1871, that the rights of the Free State claimants to the farms Scholtzfontein, Waterbak, and other farms must be judged of as if those farms lay in the Free State and were subject to Free State law".

31 Carter $v$ Van Niekerk at 460. 
and under the surface of the land in question. ${ }^{32}$ The defendants' defence was that the clause that had been inserted into the title deed constituted an express reservation of the rights to all diamonds found on the relevant farm in favour of the Government. ${ }^{33}$ Chief Justice Maasdorp, however, held that the Government could not reserve to itself what it had not already possessed. He held that in the case of an original quitrent grant of unalienated Crown land, the Government was entitled to reserve to itself as much of the ownership of such Crown land and of the rights attaching to the land as it wanted to, but it could not reserve to itself what belonged to the owner of the land that had already been alienated. ${ }^{34}$ Prior to the issue of the grant of 15 July 1880 , the owner's predecessors in title were entitled to receive a grant confirming the perpetual quitrent from the Orange Free State with all the rights attaching thereto the Government of the Orange Free State would not have been entitled to claim the ownership in such precious stones and the Government of Griqualand West similarly had no such right. ${ }^{35}$

Van Niekerk and the Union Government appealed to the Appellate Division, ${ }^{36}$ but Innes CJ dismissed the appeal and stated that the farm never belonged to the Government of Griqualand West. The land in question was private property at the date of annexation of Griqualand West as part of the Cape Colony and it remained private property thereafter. ${ }^{37}$ The Appellate Division referred to the decision in Webb $v$ Giddy in which it was decided that a similar grant made by the Government of the Orange Free State conveyed not mere emphyteutic rights, but also the ownership of the soil, including the diamonds and minerals which it contained. The Appellate Division held that the grant initiated by the Governor in 1880 had to be interpreted as conferring the same mineral rights as the Orange Free State title for which it was substituted. Regarding the term "perpetual quitrent" Innes CJ stated as follows: ${ }^{38}$

That was a term in general use in South Africa to describe a tenure, the incidents of which might greatly vary. Upon the common law meaning it is not necessary to dilate; but that meaning had been fundamentally modified in different localities. In the Cape it had become a form of ownership governed first by Sir John Cradock's Proclamation (1813), and thereafter by the provisions of Act 14 of 1878. In the Free State it had evolved into a tenure which, as decided by the Privy Council, gave the minerals to the owner. By Griqualand West Ordinance 3 of 1874 certain statutory incidents were assigned to it, which included a reservation of precious stones, gold and silver to the Crown. But that measure regulated the disposal of unalienated or waste lands; it was not intended to apply and could not apply to grants issued in terms of the quieting proclamation in substitution for Free State titles.

Ibid. This is in accordance with the cuius est solum principle.

Idem at 466 .

Ibid.

35 Carter v Van Niekerk 467.

36 Van Niekerk and Union Government (Minister of Lands) v Carter 1917 AD 359.

37 Idem at 372.

38 Idem at 379. 
The Appellate Division also referred to the position with regard to other farms along the Vaal River which had been originally held under Free State title and stated that the Cape Government was for a long time willing to rectify titles which purported to reserve mineral rights to the Crown. After the annexation of the Griqualand West as part of the Cape Colony, the Cape Government, in an attempt to rectify the position, began to issue "clean titles" which clearly gave the minerals in the land to the landowner in exchange for titles that either reserved them to the Crown or purported to be without prejudice to any rights the Crown possessed. This practice was, however, discontinued after the Government had issued seventy-five "clean titles". 39

\section{The 1872 GW Prospecting Proclamation}

Prior to the issue of the 1872 GW Prospecting Proclamation there was no statutory provision in Griqualand West regulating the prospecting or searching for diamonds in respect of land that had not already been proclaimed as a diamond field. Before the commencement of the $1872 \mathrm{GW}$ Prospecting Proclamation, a person who wanted to prospect on land that belonged to another person where no diamond field had been proclaimed, had to require the consent of the landowner.

The position was amended with the proclamation of the $1872 \mathrm{GW}$ Prospecting Proclamation, but only in respect of private property. ${ }^{40}$ The purpose of the 1872 GW Prospecting Proclamation was twofold. It firstly provided regulations for the payment of licences for prospecting on private property for precious stones, gold or silver. Secondly, it determined the rate of digging licences on such parts of the private property that had not previously been proclaimed as a public diamond field. The term "private property" was not defined in the 1872 GW Prospecting Proclamation. There was no proviso that the term "private property" referred only to reserved private land. ${ }^{41}$ The consequence was that unreserved private land ${ }^{42}$ was included and regulated under the $1872 \mathrm{GW}$ Prospecting Proclamation. ${ }^{43}$

39 A bill was introduced into the Cape Parliament by the Government to delete from the title deeds of all properties originally held under Free State title any conditions referring to the mineral rights of the Crown. The bill was never enacted and in Van Niekerk and Union Government (Minister of Lands) $v$ Carter at 382, Innes CJ remarked as follows in regard to the failure to remove the conditions from the title deeds: "There are, it would seem, certain titles of the Free State farms still in existence which contain an express reservation of minerals in favour of the Crown. It is clear now that those minerals did not belong to the Crown, and that clean titles should have been issued in such cases. I venture to think that the fitting course for the Union Government to take is to divest itself of rights which it could only have reserved under a mistaken view of the law; and by legislation or otherwise to take steps to restore such rights to those entitled to them."

40 On 7 Nov 1872, two of the three Commissioners issued the 1872 GW Prospecting Proclamation.

41 Referred to in this article as private land, the title deed of which was subject to the reservation of the rights to diamonds in favour of the Crown.

42 Referred to in this article as privately owned land, the title of which did not contain a reservation of the right to diamonds in favour of the Crown or anyone else.

43 Section 8 of the 1872 GW Prospecting Proclamation. 
With reference to its first objective, section 1 of the $1872 \mathrm{GW}$ Prospecting Proclamation provided that the Civil Commissioner of any district within which private property was situated would be entitled to issue a prospecting licence, authorising the holder thereof to prospect for the period of one month on any part of the relevant private property that was not a proclaimed diamond field. ${ }^{44}$

There was no reference in the $1872 \mathrm{GW}$ Prospecting Proclamation to the fact that any of the provisions of the 1871 GW Diggings Proclamation had been repealed. It is submitted that a person who wanted to prospect for diamonds on unreserved private land, would only have been entitled to obtain a prospecting licence regarding such land if it is with the consent of the landowner. It is not clear why a landowner of unreserved private land would have been obliged to allow the holder of a prospecting licence to prospect for diamonds on his land if the landowner could not be compelled to consent to the establishment of diggings on his land. ${ }^{45}$

In the case of reserved private land, the consent of the landowner was not required to obtain a prospecting licence and the landowner could not exclude prospectors from his land. ${ }^{46}$

\section{Rights and obligations of the prospector}

A digger who found diamonds, gold or silver while prospecting under a prospecting licence was obliged to report the finding to the Civil Commissioner of the district. ${ }^{47}$ Diggers who found diamonds while working under a prospecting licence was entitled to the free grant of two claims of thirty square feet each at the place where the diamonds had been discovered..$^{48}$ The 1872 GW Prospecting Proclamation did not apply in respect of Crown land. Thus, a person who found diamonds on Crown land was not entitled to the rights of a discoverer as provided in section 6 of the $1872 \mathrm{GW}$ Prospecting Proclamation. It is submitted that in the case of unreserved private land, the digger would only be entitled to be granted two claims if the landowner consented

44 The licence fees payable in respect of each prospecting licence were prescribed in s 2 of the 1872 GW Prospecting Proclamation. In the case of a party of not more than three persons, an amount of one pound sterling was payable for a monthly licence. In the case of a party of more than three and not more than ten persons, an amount of two pounds sterling was payable. In the case of a party of more than ten persons, an amount of four shillings was payable for every person above ten, in addition to the two pounds sterling.

45 This appears to be the correct interpretation: years later, with the issue of Griqualand West Procl 8 of 1880 dated $30 \mathrm{Sep} 1880$, it was noted in the prescribed form for a prospecting licence that the consent of the landowner of unreserved private land was required in order to prospect on unreserved private land.

46 Union Government (Minister of Mines) v Thompson at 421.

47 Section 3 of the 1872 GW Prospecting Proclamation. Failure to report a finding would upon conviction before a magistrate result in the forfeiture of the prospecting licence and to the payment of a fine not exceeding twenty pounds sterling and in the event of default of payment, to imprisonment with or without hard labour for any period not exceeding three months.

48 Section 6 of the 1872 GW Prospecting Proclamation. Previously at the river diggings, the Diggers Republic's Rules provided that the discoverer was entitled to be awarded four claims. 
to the establishment of diamond diggings on his land under the $1871 \mathrm{GW}$ Diggings Proclamation. The previous position that applied under the $1871 \mathrm{GW}$ Diggings Proclamation in terms of which the landowner was entitled to determine the rate at which digging licences would be issued, ${ }^{49}$ was amended with the proclamation of the 1872 GW Prospecting Proclamation. The maximum amount for digging licences as determined by the landowner of unreserved private land was fixed at one pound per month. ${ }^{50}$ No provision was made for the renewal of prospecting licences granted in terms of the $1872 \mathrm{GW}$ Prospecting Proclamation.

\section{Interests of the landowner}

Certain measures were adopted to protect the interests of landowners. An applicant for a prospecting licence was obliged to provide security for payment of twenty pounds sterling in the form agreed to by the Civil Commissioner in order to indemnify the landowner against any surface damage resulting from the prospecting operations. ${ }^{51}$ The holder of the prospecting licence was also not entitled to search for diamonds within a distance of one hundred yards of any house or building that the landowner or occupier of the land used without the consent of such landowner or occupier. ${ }^{52}$ Prospecting on any land under cultivation was also prohibited unless the landowner or occupier consented thereto. ${ }^{53}$ These measures did not apply in the case of prospecting for diamonds on Crown land. There were also no similar restrictions in respect of the working of claims on proclaimed diamond fields.

\section{Diamond fields on Vooruitzigt, Dutoitspan and Bultfontein}

By the end of 1871, the diggings known as De Beers, Kimberley, Bultfontein and Dutoitspan were divided into approximately 3200 full claims and many of them were further subdivided..$^{54}$ They were situated on private land and there was no reservation of the rights to diamonds in favour of any Government or the Crown in the title deeds of the land on which the mines were situated..$^{55}$ On 17 November 1871, two of the local Commissioners issued three proclamations establishing diamond fields on the

49 Section 29 of the 1871 GW Diggings Proclamation.

50 Section 8 of the $1872 \mathrm{GW}$ Prospecting Proclamation. The amounts payable to the landowner were also subject to the withholding of charges for the Government's expenses.

51 Section 5 of the 1872 GW Prospecting Proclamation.

52 Section 7 of the 1872 GW Prospecting Proclamation.

53 Section 7 of the 1872 GW Prospecting Proclamation. Prospecting without a prospecting licence was in terms of s 4 of the $1872 \mathrm{GW}$ Prospecting Proclamation punishable by a fine not exceeding twenty pounds sterling and in the event of default of payment, to imprisonment with or without hard labour, for any period not exceeding one month.

54 Davenport 2009: 52, 55.

55 Beaconsfield Municipality v London and SA Exploration Co Ltd 18843 HCG 183; London and SA Exploration Co v Bultfontein Mining Board 1888-1889 6 SC 201 at 212. 
farms Vooruitzigt, ${ }^{56}$ Dutoitspan ${ }^{57}$ and Bultfontein. ${ }^{58}$ It was recorded in the preambles of all three proclamations that the titles of these three farms were not subject to the reservation of minerals and precious stones in favour of the Crown. Thus, for the purposes of this article, it was unreserved private land. ${ }^{59}$

\section{Second period: Griqualand West designated as a Province (1873 to 1879)}

The three Commissioners were not successful in governing Griqualand West. They were situated in the different districts of Klipdrift, Pniel and Griqua Town which made uniform government difficult. They often held different and conflicting views on matters and were faced with numerous challenges, at the centre of which were the technological and operational problems that the diggers faced and with which legislation did not keep up. ${ }^{60}$

Circumstances at the diggings in Griqualand West deteriorated. Allowing diggers to own individual claims, permitted the diggers to remove the soil within each claim at their own time, which often resulted in ground slides between adjoining claims since not all diggers worked their claims at the same rate. ${ }^{61}$ It became evident that

56 Griqualand West Procl 30 of 17 Nov 1871. This proclamation was later repealed in terms of Griqualand West Ord 5 of 1874.

57 Griqualand West Procl 31 of 17 Nov 1871. This proclamation was later repealed in terms of Griqualand West Ord 5 of 1874.

58 Griqualand West Procl 32 of 17 Nov 1871. This proclamation was later repealed in terms of Griqualand West Ord 5 of 1874.

59 The appointed local Commissioners further issued proclamations under the $1871 \mathrm{GW}$ Diggings Proclamation, in which they made provision for the establishment of diamond fields on a number of portions of Crown land. In Griqualand West Procl 33 of 1871 dated 28 Nov 1871, diamond fields were established on Crown lands at Pniel, Webster's Kopje, Cawoods' Hope and Blue Jacket in the District of Kimberley. On the same day, Griqualand West Procl 34 of 1871 was issued, establishing diamond fields on Crown lands at Hebron, Good Hope, Bad Hope, Gong Gong, Union Kopje, Keiskamma, Forlorn Hope, Esterhuizen's Rush, Winter's Rush and Delport's Hope in the Barkly District. Griqualand West Procl 35 of 8 Dec 1871 established diamond fields on Crown lands at Longland's Rush, in respect of the area between Winter's Rush and Delport's Hope in the Barkly District. Griqualand West Proc 39 of 1872 dated 10 Jan 1872 was issued to establish diamond fields on Crown land between Upper Klipdrift and Good Hope. Griqualand West Procl 53 of 4 Sep 1872 established a diamond field at Waldek's Plant.

60 Davenport 2009: 52. The Commissioners sometimes made irrational decisions. In Griqualand West Procl 47 of 23 Jul 1872 they proclaimed that all digging licences held by so-called natives and coloured people were ordered to be suspended and they imposed restrictions on the renewal of such licences. The proclamation was issued, following complaints of theft and serious riots. This proclamation was cancelled by Sir Barkly on 10 Aug 1872.

61 Turrell 1987: 11-12 describes the method of diamond digging in Griqualand West during those early years as follows: "[D]igging was conducted on a damaging, haphazard basis. Soil taken out of a claim was sorted on an adjacent one; water was struck after forty feet and so each hole was filled in and another one begun. Dutoitspan was so badly worked, wrote one official, 'that there are not ten full claims worked to a depth of forty feet, although it has been worked for eighteen months longer than Colesberg Kopje [Kimberley Mine] and there is not an average depth of ten 
amalgamation of the claims was the solution, not only to prevent ground slides, but also to reduce the rising costs of diamond digging. ${ }^{62}$ The "jumping" system which provided that claims of diggers who failed to work their claims continuously and bona fide for purposes of extracting diamonds could be "jumped" by other diggers, was regarded as the main opposition to the consolidation of the claims. ${ }^{63}$

The diggers at Griqualand West were furthermore concerned that the main focus of the Government of the Cape Colony was on the farming industry and that laws adapted for agriculture such as those of Cape Town and the rest of the Cape Colony, were not suitable for the mining community of Griqualand West. They desired a representative government situated in Griqualand West. ${ }^{64}$

On 30 November 1872 Sir Barkly cancelled the appointment of the three local Commissioners ${ }^{65}$ and appointed Richard Southey as administrator with full authority to govern Griqualand West on his behalf. ${ }^{66}$ Six months later, Sir Barkly declared that

feet.' Sorting inside the mine obstructed digging as debris mounds were left upon productive soil. In an attempt to encourage diggers to take soil out of the mines, a central road, running across the pits, was left intact in Bultfontein and Dutoitspan, while in Kimberley Mine a road system was adopted on a grand scale. Across the pit from north to south fourteen roads were laid. Each claim surrendered seven and a half feet along one side and backed with its adjacent claim made roads fifteen feet in width. The soil was hauled out of the claims in buckets, loaded on to waiting carts or wheel barrows on the roadways and then taken out of the pit to diggers' encampments for sorting. But the roadway system could not last. Diggers undermined the roadways in their search for diamonds and by April 1872 the system had developed into a death trap." See also Davenport 2009: 53. In regard to the duty of a claimholder to work his claim with reasonable diligence, see Murtha v Von Beek 1880-1884 1 Buch AC 121; Reed v De Beers Consolidated Mines Limited 9 1892 Juta SC 33. See, also, Dale 1979: 301, 334.

62 The price of diamonds also decreased as result of the large number of diamonds found, and consequently flooded the European market. See Worger 1987: 21; Davenport 2009: 52-54.

63 William Hall, who was regarded as a monopolist and who was the owner of the first steam engine on the diamond fields, stated the following in his written submission to the 1873 Diamond Fields Commission: "(T)he benefits to the community is the same whether the claims are owned by one man or a hundred. To restrain the investment of capital in the mine would be injurious to the present holders of ground, opposed to advancement and by adopting principles that are far behind the age and have always failed. It would also drive all our most intelligent and enterprising men from our midst and would be a permanent injury to a new state like this. By restricting what a man may acquire an end is put to all progress which is the very soul of a new country. If a man is only to hold two claims why not prevent him from holding more than two farms or two houses or two stores or two carts, in fact, if 'individual levelling' is going to be adopted we had better at once call ourselves 'Chartists' or 'Fenians' or 'Communists' or the latest improvement 'internationalists' and redivide the claims in Colesberg Kopje' [Kimberley Mine] every month.” See Turrell 1987: 35 .

64 It was still not an appropriate time for the Government of the Cape Colony to annex Griqualand West as part of the Cape Colony. A bill for the annexation of Griqualand West was passed on 18 Apr 1872 by the Government of the Cape Colony. The bill was withdrawn without putting it to the vote. This was because there was a dispute between the members of Parliament as to whether Griqualand West should be annexed as part of the Cape Colony. Some members of Parliament supported the Government of the Orange Free State's claim to Griqualand West and they were in favour of a united South Africa. They feared that the annexation of Griqualand West would result in hostility from the Government of the Orange Free State.

65 By Griqualand West Procl 75 of 30 Nov 1872.

66 By Griqualand West Procl 76 of 30 Nov 1872. 
the territory of Griqualand West would be designated the Province of Griqualand West. He also proclaimed Richard Southey as the Lieutenant-General of Griqualand West. ${ }^{67}$ In the first few months, following the appointment of Richard Southey first as administrator and thereafter as Lieutenant-General, he had to rule by proclamation since no constitution for Griqualand West had been drawn up. ${ }^{68}$

\section{Suspension of the "jumping" system}

Southey issued two of the very first proclamations dealing with the mining of diamonds immediately after his appointment as Administrator of Griqualand West. In the first Griqualand West Proclamation 2 of 31 January 1873, he suspended the operation of sections 11 and 16 of the 1871 GW Diggings Proclamation until 15 March $1873 .{ }^{69}$ Roberts $^{70}$ states that, although the majority of the diggers supported the suspension of the "jumping" system, it was one of the very first indications of the direction in which Southey wanted the diamond diggings to move, namely to destroy the authority of the Diamond Diggers' Committees. Southey viewed the "jumping" system as part of the rules emanating from the Diggers' Committees which prevented capitalist enterprise. ${ }^{71}$

In the second Griqualand West Proclamation 5 of 26 February 1873, Southey appointed a Commission to report to him on the status of the diamond fields at Colesberg Kopje, De Beers, Dutoitspan and Bultfontein, together with the regulations under which the diamond fields were being worked. The Commission was also instructed to recommend future measures for their management. ${ }^{72}$ In 1873 ,

67 By Griqualand West Procl 21 of 5 Jul 1873.

68 This was contrary to previous promises made by Sir Barkly to the diggers, that Griqualand West would have a representative Government. See Meredith 2007: 33, 41-42; Roberts 1984: 115-119.

69 Section 11 of the $1871 \mathrm{GW}$ Diggings Proclamation provided that where a person became disentitled to a claim, the Inspector could grant the claim to any other person who applied for such claim, provided that the licence fee was paid. Section 16 of the 1871 GW Diggings Proclamation provided for the "jumping" system and stated that if the holder of a claim failed to bona fide work a claim for eight days, it was deemed that the holder was disentitled to the claim. Southey hereafter continued to issue proclamations providing for the suspension of ss 11 and 16 of the 1871 GW Diggings Proclamation until Jan 1874.

70 Roberts 1984: 113.

71 Idem 112-113 describes Southey's views as follows: “In his view the Diggers' Committees were both dangerous and subversive. He openly admitted to his 'object of curbing or getting rid of the Diggers Committees' and establishing the blow, Southey then announced his intention to set up a commission to 'determine more definitely what officers or bodies should be entrusted with the control of matters' on the diamond fields. Five prominent diggers, including leading members of the Diggers' Committees, were appointed to the commission. This was to be the first step towards establishing Mining Boards. Significantly the commission was headed by J.B. Currey." According to Roberts, Currey also disliked the Diggers Committees, he regarded them as a mob rule with their main purpose to destroy the privileges of the affluent miners. Currey was shortly thereafter appointed as Government Secretary to assist Lieutenant-General Southey.

72 Roberts 1984: 112-113. 
the Commission concluded that the "jumping" system did not ensure or contribute to the uniform working of a pit. They did, however, realise that the "jumping" system should be retained in one form or another to avoid that a small number of diggers dominate the diamond diggings. The Commission recommended that the "jumping" system be amended to provide that the forfeited claims could only be auctioned after a notice of demand had been given. ${ }^{73}$

The diggers insisted that an election be held and that a representative government for Griqualand West be elected. ${ }^{74}$ Contrary to the previous promises of Sir Barkly, namely that Griqualand West would have a representative government, the Legislative Council of the Province of Griqualand West comprised of eight members, of which only four members would be elected, two from the district of Kimberley and one each from the districts of Barkly and Hay. The Government of Griqualand West would nominate the remaining four members. Southey was left with a casting vote and had the power to veto legislation. The Legislative Council of Griqualand West met for the first time on 30 December $1873 .^{75}$

The Province of Griqualand West passed its first ordinance, Griqualand West Ordinance 1 of 1874 on 30 January 1874, in which the recommendations of the Commission were adopted. ${ }^{76}$ Griqualand West Ordinance 1 of 1874 provided for the suspension of section 11 of the 1871 GW Diggings Proclamation insofar as it provided that the Inspector of Claims was obliged to grant licences for forfeited claims or to put up such claims to public auction. It was stated in the preamble that Griqualand West Ordinance 1 of 1874 was passed, pending the passing of an ordinance for the better management of mines and diggings in Griqualand West.

73 Turrell 1987: 34-35

74 The diggers insisted that an election be held and that a representative government for Griqualand West be elected. The British Secretary for the British Colonies, Lord Kimberley, insisted that before electoral divisions could be defined, the areas should receive decent and intelligible names. According to Roberts 1984: 115-119, Lord Kimberley - "declined to be in any way connected with such a vulgarism as New Rush and for Vooruitzigt ... he could neither spell nor pronounce it. Klipdrift and Griquatown were not much better and he requested that English speaking names might be given to the Districts round the Mining Camps". Lord Kimberley's request was passed on to Southey, who handed it to Currey. Sir Barkly issued Griqualand West Procl 22 of 1873 dated $5 \mathrm{Jul} 1873$ to make provisions for the change of names and towns within Griqualand West. The proclamation was divided into three electoral divisions, Kimberley, Barkly and Hay. The name of the previous district of Pniel was changed to the district of Kimberley, in honour of Lord Kimberley. The encampment previously known as Colesberg Kopje or the New Rush, was called the town of Kimberley. The name of the previous district of Klipdrift was changed to the district of Barkly, in honour of the Governor Sir Barkly and it included the diggings along the Harts River and the Vaal River. The name of the town of Klipdrift was changed to Barkly. The name of the district of Griquatown was changed to the district of Hay, partly in memory of a Scottish town that Currey had known in his youth and partly in honour of the previous acting Governor of the Cape Colony. See Doughty 1963: 97.

75 Meredith 2007: 41-42.

76 Griqualand West Ord 1 of 1874 took effect on 9 May 1874. 
Section 16 of the 1871 GW Diggings Proclamation which provided for the "jumping" system, was not suspended with the result that claims would have lapsed if the holder thereof ceased bona fide to work the claims for a period of eight days. ${ }^{77}$

\section{Public diamond fields on Vooruitzigt, Dutoitspan and Bultfontein}

Almost three years after the proclamation of diamond fields on the farms Vooruitzigt, Dutoitspan and Bultfontein, the Legislative Council of the Province of Griqualand West passed Griqualand West Ordinance 5 of 1874 on 11 March 1874 in order to make provision for the repeal of the three earlier Proclamations establishing diamond fields on the privately owned farms Vooruitzigt, Dutoitspan and Bultfontein. It was recorded in the preamble of Ordinance 5 of 1874 that doubts had arisen as to whether the three earlier Proclamations ${ }^{78}$ had been duly and lawfully promulgated and further that the Government of the Griqualand West Province had been advised that the titles to the farms Vooruitzigt, Bultfontein and Dutoitspan were indeed subject to reservations of minerals and precious stones in favour of the Crown. ${ }^{79}$ Two months later, seven areas situated within the District of Kimberley were proclaimed as public diamond fields by virtue of the Griqualand West Proclamation 6 of 4 May 1874 . These areas included the farms Vooruitzigt, Dutoitspan and Bultfontein. ${ }^{80}$ The effect

77 The Legislative Council of the Province of Griqualand West adopted Griqualand West Ord 3 of 1874 on $26 \mathrm{Feb} 1874$ to provide for the leasing of Crown land and for the purchase thereof (hereafter the 1874 GW Crown Land Ord). Sections 1-4 of the 1874 GW Crown Land Ord provided that the Governor of the Province of Griqualand West could - by public auction - let certain "waste" Crown Lands for a period not exceeding twenty-one years, subject to conditions imposed by the Governor and agreed to by the lessee and subject to the payment of an annual rental. Section 5 of the 1874 GW Crown Land Ord specifically reserved the rights to all minerals and precious stones found in the leased areas to the Crown. A lessee could furthermore in terms of s 6 of the $1874 \mathrm{GW}$ Crown Land Ord, at any time during the duration of the lease, convert the leasehold to perpetual quitrent tenure, at such price as may be agreed to between the lessee and the Governor. The conversion of the leasehold to perpetual quitrent, was inter alia subject to the following conditions: Firstly, the purchaser, in addition to the payment of a purchase price, had to pay in perpetuity, an annual quitrent of two pounds sterling for every hundred pounds or fraction of hundred pounds, on the purchase price. Secondly, the purchaser was on payment of the purchase price entitled to require a grant of perpetual quitrent title to the land previously held by him under lease. The land held under perpetual quitrent title was also subject to the reservation of precious stones and of gold and silver found therein, in favour of the Crown.

78 Griqualand West Procl 30 of 17 Nov 1871, Griqualand West Procl 31 of 17 Nov 1871 and Griqualand West Procl 32 of 17 Nov 1871. See Cape of Good Hope Report 1882: par 32.

79 Section 2 of Griqualand West Ord 5 of 1874 provided that the Governor of the Griqualand West Province could, with the advice of the Executive Council, proclaim such areas throughout the province as may be necessary, to be public diamond fields in accordance with the $1871 \mathrm{GW}$ Diggings Proclamation.

80 The first three areas were situated on the farm Vooruitzigt, the fourth and sixth on the farm Bultfontein, the fifth on the farm Dutoitspan. A seventh area was proclaimed on the farm Alexanderfontein. 
of the latter proclamations was that the landowners of these farms were no longer entitled to receive any rental or royalties in terms of section 29 of the $1871 \mathrm{GW}$ Diggings Proclamation. ${ }^{81}$

The proprietary status of the farms Vooruitzigt, Dutoitspan and Bultfontein later came under scrutiny in a number of cases before the High Court of Griqualand West. ${ }^{82}$ In Webb $v$ Giddy the agent (Webb) of the landowner of the farm Dutoitspan instituted action against the Government on 5 November 1875 for the payment of all licence monies, royalties or rents collected by the Government from 17 November 1871 in respect of the diggings situated on the farm Dutoitspan, and for an account of the amount which the Government retained to defray the public expenditure for the maintenance of order and good government at the farm Dutoitspan. The Government (represented by Giddy, one of the Commissioners appointed in respect of Griqualand West) pleaded that the farm Dutoitspan was held under perpetual quitrent and that it was therefore subject to a reservation of precious stones and minerals to the State as dominus directus of the soil and that all rights that formerly vested in the Government of the Orange Free State were vested in the British Crown. The Government further contended that all payments which had been made to the landowners in terms of section 29 of the 1871 GW Diggings Proclamation had been made in error. It was common cause that the Government of the Orange Free State had previously granted the farm Dutoitspan to its first owner and that the following condition was contained in the initial grant:

That the said land will further be subject to all conditions and regulations as are already, or may in future, be fixed, referring to lands granted on the same conditions; and, lastly that the owner shall be bound to the prompt payment of a yearly quitrent of the sum of $£ 1.10 \mathrm{~s}$ sterling.

The Privy Council agreed with the judgment of the High Court of Griqualand West in which it was held that the landowner of the farm Dutoitspan was entitled to receive a portion of the licence fees as provided for in section 29 of the $1871 \mathrm{GW}$ Diggings Proclamation. On 13 May 1874, the Legislative Council of the Province of Griqualand West adopted the Griqualand West Ordinance 10 of 1874 (hereafter

81 Griqualand West Ord 5 of 1874 was later disallowed by Queen Victoria of England in terms of Cape GN 35 of 5 Apr 1875. The legality of the mining areas that were constituted pursuant to Griqualand West Ord 5 of 1874 was later doubted as a result of the disallowance of Griqualand West Ord 5 of 1874 . Griqualand West Ord 21 of 1880 dated 24 Sep 1880 was later passed to confirm the legality of the first three mining areas situated on the farm Vooruitzigt. Griqualand West Ord 21 of 1880 was confirmed by Queen Victoria in terms of Cape GN 33 of 10 Jan 1881.

82 In London and SA Exploration Co Ltd v Trustees of Isaacs \& Co 18843 HCG 174, the High Court of Griqualand West accepted that the farm Dutoitspan was a privately owned farm and that the title deed of the land contained no reservation of the rights to diamonds in favour of the Crown. See also Bultfontein Mining Board v Armstrong 1890-1892 6 HCG 57, in relation to the farm Bultfontein. 
the 1874 GW Mining Ordinance) ${ }^{83}$ empowering the Governor of the Province of Griqualand West to make rules and regulations for the management of diggings and mines within the Province of Griqualand West ${ }^{84}$ and to demand the payment of a prescribed sum of money from persons digging or mining for precious stones or minerals within the province. ${ }^{85}$

\section{GW Mining Ordinance}

General rules and regulations for the management of diggings and mines were included in a schedule to the $1874 \mathrm{GW}$ Mining Ordinance and applied until the cancellation or amendment thereof. ${ }^{86}$ The schedule included rules regulating the prospecting for diamonds and the working of established and new diggings and further provided for the conversion of a digging to a mine. The $1874 \mathrm{GW}$ Mining Ordinance was the first legislation in which the working of alluvial diggings and the mining of diamonds were separately regulated.

The 1874 GW Mining Ordinance repealed the 1871 GW Diggings Proclamation and all other legal enactments which may be repugnant or inconsistent with any of the provisions of the Ordinance. ${ }^{87}$ Section 4 of the 1874 GW Mining Ordinance provided as follows:

All and singular the provisions of the Proclamation of His Excellency Sir Henry Barkly, K.C.B., No 71 (No. 5) of the $27^{\text {th }}$ of October, 1871, and of any other Proclamations, Government Notices, or other legal enactments, which may be repugnant to or inconsistent with any of the provisions of this Ordinance or of any Rules and Regulations now or hereafter to be enacted by the Legislature of this Province for the management of Diggings and Mines, or for regulating the searching for precious stones and metals, shall and the same hereby are cancelled and repealed.

There are two possible interpretations of section 4 of the 1874 GW Mining Ordinance. The first is that the whole of the $1871 \mathrm{GW}$ Diggings Proclamation was repealed. The second, which appears to be the correct interpretation, is that only those provisions that were inconsistent with the $1874 \mathrm{GW}$ Mining Ordinance and its rules and regulations were repealed. The whole of the $1874 \mathrm{GW}$ Mining Ordinance

83 The 1874 Griqualand West Mining Ord was published in the Griqualand West GG of 4 Jun 1874 and was confirmed by Queen Victoria in terms of Cape GN 35 of 1875.

84 Section 1 of the 1874 GW Mining Ord; Bank of Africa v Kimberley Mining Board 18843 HCG 371 at 395 (hereafter the Bank of Africa case).

85 Section 3 of the 1874 GW Mining Ord.

86 Section 5 of the 1874 GW Mining Ord.

87 Section 4 of the 1874 GW Mining Ord.

88 Section 1 read with the first schedule of the Precious Stones and Minerals Mining Act 19 of 1883. Furthermore, s 9 of Griqualand West Procl 8 of 1880 dated 30 Sep 1880, specifically referred to ss 23-28 of the $1871 \mathrm{GW}$ Diggings Proclamation insofar as it was still applicable. See, also, London and SA Exploration Co Ltd v Dutoitspan Mining Board 18832 HCG 154; London and SA Exploration Co v Murphy 1886-1887 4 HCG 125 at 330; London and SA Exploration Co v Bultfontein Mining Board at 217. 
was only repealed on 27 September 1883 with the commencement of the Precious Stones and Minerals Mining Act 19 of $1883 .{ }^{88}$

There was no statutory reservation of the rights to diamonds in favour of the British Crown or the Government of the Cape Colony in the 1874 GW Mining Ordinance. The question as to who was entitled to prospect for diamonds or to work claims in diggings or to mine for diamonds continued to depend on the specific form of land tenure. The rules and regulations contained in a schedule to the $1874 \mathrm{GW}$ Mining Ordinance only applied in respect of Crown land and reserved private land and not in respect of unreserved private land. ${ }^{89}$

\section{Rights and obligations of a prospector}

Any person that wanted to prospect for diamonds ${ }^{90}$ on Crown land or reserved private land ${ }^{91}$ first had to register as a miner and had to take out a prospecting licence at the office of the Civil Commissioner. ${ }^{92}$ The 1874 GW Mining Ordinance did not apply to prospecting for diamonds on unreserved private land and it is submitted that the 1871 GW Diggings Proclamation read with the 1872 GW Prospecting Proclamation continued to apply in respect of the prospecting for diamonds on unreserved private land.

The discoverer, who discovered the diamonds under a prospecting licence, was entitled to select and to mark off the ground for his two claims. ${ }^{93}$ The claims had to be measured and numbered, boundary lines determined, and a plan prepared. Notice was then given of a specific day on which claims would be allocated to certificated miners. ${ }^{94}$ Once at least two-thirds of the claims applied for had been allocated and registered, the Inspector or Overseer had to define the reserved areas outside the claims which the miners could use in addition for mining purposes. ${ }^{95}$

89 The preamble of the schedule to the 1874 GW Mining Ord provided that it contained "General Rules and Regulations for the management of Diggings and Mines of Precious Stones and Minerals on Crown Lands, or on Private Properties in which the Precious Stones and Minerals belong to the Crown, in the Province of Griqualand West".

90 Item 1 of s 7 of the schedule to the 1874 GW Mining Ord referred to "precious stones or minerals".

91 Referred to in this article as privately owned land, the title of which contained a reservation of the right to diamonds in favour of the Government.

92 Item 1 of s 7 of the schedule to the 1874 GW Mining Ord referred to a "certificated miner". The certificated miner had to pay a monthly licence fee of one pound for a party of not more than one miner and two servants. Item 2 of s 7 of the schedule to the 1874 GW Mining Ord provided that a fee of ten shillings a month was payable for every additional miner and five shillings for every additional servant.

93 See item 4 of s 3 read with item 5 of s 7 of the schedule to the 1874 GW Mining Ord. Every claim had to be thirty square feet. The size of the claims could be amended by proclamation or by-laws, adopted in respect of the digging. See item 19 of s 1 of the schedule to the 1874 GW Mining Ord.

94 See item 5 of s 3 of the schedule to the 1874 GW Mining Ord.

95 Item 6 of s 3 of the schedule to the 1874 GW Mining Ord. 


\section{Rights and obligations of a claimholder and miner}

In the case of the discovery of a new digging ${ }^{96}$ on Crown land or on reserved private land, the Inspector or Overseer ${ }^{97}$ had to attend at the specific area for the purpose of registering the claim. After six months from the date of proclamation of a new digging, all new diggings were deemed to be established diggings. ${ }^{98}$ There was no definition of "established diggings" in the 1874 GW Mining Ordinance or in the schedule thereto. There were also no transitional provisions to confirm that diggings, which were proclaimed in Griqualand West under the $1871 \mathrm{GW}$ Diggings Proclamation on Crown land and on reserved private land, would be established diggings as contemplated in section 4 of the schedule to the $1874 \mathrm{GW}$ Mining Ordinance. ${ }^{99}$

The $1874 \mathrm{GW}$ Mining Ordinance further provided for the conversion of a digging into a mine. ${ }^{100}$ Once a digging is declared to be a mine, the Governor had to appoint a Registrar and Engineer or Surveyor for such mine. ${ }^{101}$ In the case of the conversion of a digging to a mine, the Governor had to request all claimholders in the mine by notice in the Gazette to elect a Mining Board. ${ }^{102}$ Each Mining Board was

96 The term "new diggings" was described in item 1 of s 3 of the schedule to the 1874 GW Mining Ord, as diggings that were proclaimed as such after the promulgation of the $1874 \mathrm{GW}$ Mining Ord.

97 Item 1 of s 2 of the schedule to the 1874 GW Mining Ord provided that the Governor could appoint such Inspectors or Overseers of claims as he deemed necessary for all diggings.

98 Item 1 of s 4 of the schedule to the 1874 GW Mining Ord.

99 Item 7 of $\mathrm{s} 3$ of the schedule to the $1874 \mathrm{GW}$ Mining Ord provided that at every digging where there were more than fifty registered claimholders, the claimholders were entitled, after submitting an application signed by at least two-thirds of the total number of claimholders to the Government, to elect a Diggers' Committee consisting of not less than five and not more than nine members. The Diggers' Committee had to make by-laws for such digging, which had to be approved by the Governor and had to be published in the Gazette. In the event that the diggers failed to elect a Diggers' Committee or where the elected Diggers' Committee failed to make by-laws, item 8 of s 3 of the schedule to the $1874 \mathrm{GW}$ Mining Ord provided that the Inspector of Claims for such digging could make by-laws for the digging which came into effect once approved by the Governor and published in the Gazette.

100 Item 1 of s 5 of the schedule to the 1874 GW Mining Ord.

101 Item 2 of s 5 of the schedule to the 1874 GW Mining Ord. Item 4 of s 5 of the schedule to the 1874 GW Mining Ord provided that the Engineer or Surveyor had the sole and entire control of the mining areas for which he was appointed. In terms of item 12 of s 1 of the schedule to the 1874 GW Mining Ord miners were obliged to comply with orders issued by qualified officers for the safe and proper working of the diggings or mines or by-laws drafted in respect of the diggings or mine. The Inspector or Engineer could - in terms of item 24 of s 1 of the schedule to the $1874 \mathrm{GW}$ Mining Ord - issue a written notice to a miner to cease digging or to cease his mining operations. He could also compel the miner to perform certain specific work or prohibit the use of a machine, engine or appliance for raising or removing rock, soil or water in a digging or mine.

102 The Mining Board had to comprise of nine members who had to be re-elected every year. Once a Mining Board had been elected, item 2 of s 5 of the schedule to the 1874 GW Mining Ord provided that the powers, duties and functions of the Diggers' Committee ceased to exist. Each Mining Board had to draft its own by-laws for the management of the mine for which it was elected. Item 8 of s 6 of the schedule to the $1874 \mathrm{GW}$ Mining Ord provided that the by-laws came into effect on the date of proclamation in the Gazette and were subject to the approval of both the Governor and the Executive Council for the Griqualand West Province. 
entitled to determine the rate which miners had to pay yearly, quarterly or monthly in respect of each claim. ${ }^{103}$

Every person of good character and older than sixteen years was entitled to obtain a miner's certificate from the Resident Magistrate for the relevant district. ${ }^{104}$ During the first six months following the proclamation of a new digging, each miner was entitled to hold only one claim which could not be transferred during the first three months. ${ }^{105}$ If a claim was unregistered or unworked for a period of seven days, excluding a Sunday or a public holiday, the Inspector or Overseer would then declare the claim abandoned unless the holder of the claim had obtained a certificate of reservation from the Inspector or Overseer. ${ }^{106}$ Any other certificated miner could apply in writing to have the claim registered in his name. ${ }^{107}$ If there was at any time during the first six months after a digging had been proclaimed, less than twelve registered claimholders, the diggings could be closed by proclamation after notice of at least one month was given to this effect. ${ }^{108}$

A miner was entitled to the free and undisturbed possession of the claims registered in his name. All claims were issued subject to a servitude of not more

103 The rate determined by the Mining Board had to be approved by the Governor and the Executive Council. Each claimholder had to pay the fee within thirty days after the payment became due, failing which it was deemed that the claim was abandoned. Item 9 of s 6 of the schedule to the 1874 GW Mining Ord provided that the claimholders had to pay the licence fees to the Registrar of the particular mine, who in turn accounted to the Treasurer of the Griqualand West Province. The Treasurer paid the amounts to the Mining Board on submission of vouchers from the Engineer or Surveyor of the Mine. Item 10 of s 6 of the schedule to the 1874 GW Mining Ord provided that the Mining Board had to apply the money for public purposes of the mine as determined by the Engineer or Surveyor of the relevant mine and agreed to by the Minister Board or as determined in the by-laws. There was no prohibition on the content of the by-laws that could be adopted by the Digger's Committees or Mining Boards, with reference to the status of a quitrent tenant or lessee. See the Bank of Africa case in relation to the functions and powers of a Mining Board and Dale 1979: 219 .

104 Item 1 of $\mathrm{s} 1$ of the schedule to the 1874 GW Mining Ord. The Resident Magistrate could, in terms of item 2 of s 1 of the schedule to the 1874 GW Mining Ord, require someone who applied for a miner's certificate to produce two competent witnesses to the character of the applicant.

105 Item 9 of s 3 of the schedule to the $1874 \mathrm{GW}$ Mining Ord. The holder of a prospecting licence who could prove to the satisfaction of the Resident Magistrate that he had found any diamonds, gold or silver under the prospecting licence, was entitled to two claims during the first six months. See item 5 of $\mathrm{s} 7$ of the schedule to the 1874 GW Mining Ord.

106 If more than one certified miner applied for such claim, the claim was sold by public auction. See item 10 of s 3 of the schedule to the 1874 GW Mining Ord.

107 Claims were not forfeited if the holder thereof obtained a certificate of reservation from the Inspector or Overseer on the grounds of sickness, necessary absence or other sufficient cause. A certificate of reservation could not be issued for a period of more than twenty working days. A Saturday was regarded as a working day. See item 11 of s 3 of the schedule to the $1874 \mathrm{GW}$ Mining Ord. If a certified miner who took up a claim, failed to register the claim within a period of ten days, the claim would also be declared abandoned and any other certified miner could apply to have an abandoned claim registered in his name. See items 4 and 7 of s 3 of the schedule to the 1874 GW Mining Ord.

108 Item 4 of s 3 of the schedule to the 1874 GW Mining Ord. 
than seven feet six inches on one side of each claim for purposes of a roadway. ${ }^{109}$ The Government was entitled to expropriate a larger portion of a claim if it required the use thereof for public purposes, subject to the payment of compensation to the holder of the claim. ${ }^{110}$ Every claim had to be worked by the claimholder or an agent who was duly authorised in writing to work the claim on behalf of the claimholder and who had to be a certificated miner. ${ }^{111}$

Claims could be registered for periods of at least one month but not exceeding twelve months. ${ }^{112}$ Claims could not be held in the name of a firm or joint-stock company and had to be registered in the name of the duly accredited agent of the firm or joint-stock company who had to be a certificated miner. ${ }^{113}$ Each person, firm or joint-stock company (through its accredited agent) could hold a maximum of ten full claims in the aggregate at any digging. ${ }^{114}$ This provided for limited amalgamation of claims but also protected the individual diggers from complete monopolisation. ${ }^{115}$ The holder of a claim in a digging was entitled to transfer or hypothecate his claim and every transfer of hypothecation had to be registered. ${ }^{116}$ Miners were entitled to subdivide their claims and to re-amalgamate their subdivided portions. ${ }^{117}$

Provision was made for the reservation of an area outside each claim for depositing ground, sifting or sorting soil and for machinery and staging. Each miner was obliged to remove any stone, rubbish or other matter which he deposited in the reserved area and failure to do so could result in penalties. ${ }^{118}$ It was recognised that it was necessary for each claimholder to have access to an area on which the diamondiferous ground could be spread out.

109 Item 14 of s 3 of the schedule to the 1874 GW Mining Ord.

110 Item 12 of s 1 of the schedule to the 1874 GW Mining Ord.

111 Item 22 of $\mathrm{s} 1$ of the schedule to the $1874 \mathrm{GW}$ Mining Ord.

112 Item 15 of s 1 of the schedule to the 1874 GW Mining Ord. See Dale 1979: 342. In London and SA Exploration Co v Murphy at 330, the holder of a claim who had given up physical control of his claims was held liable as he was registered as the owner of the claims.

113 Item 9 of s 1 of the schedule to the 1874 GW Mining Ord. See, further, Dale 1979: 341.

114 Item 18 of s 1 of the schedule to the 1874 Mining Ord. This restriction was later repealed by Griqualand West Ord 12 of 1876 dated 20 Nov 1876.

115 Davenport 2009: 56-57. The provisions that applied in respect of diggings regarding the number of claims that could be held by claimholders (item 18 of s 1 of the schedule to the $1874 \mathrm{GW}$ Mining Ord), the transfer of claims (item 16 of s 1 of the schedule to the 1874 GW Mining Ord), the subdivision of claims (item 36 of s 1 of the schedule to the 1874 GW Mining Ord) or the reamalgamation of claims (item 37 of s 1 of the schedule to the 1874 GW Mining Ord), and the hypothecation of claims (item 16 of s 1 of the schedule to the 1874 GW Mining Ord) applied similarly in the case of mines.

116 Item 16 of s 1 of the schedule to the 1874 GW Mining Ord. Prior to the proclamation of the 1874 GW Mining Ord, there was no provision for the hypothecation of claims. See SA Loan Mortgage and Mercantile Agency v Cape of Good Hope Bank and Littlejohn 1888-1889 6 SC 163.

117 Items 36 and 37 of s 1 of the schedule to the 1874 GW Mining Ord.

118 Item 30 read with item 26 of s 1 of the schedule to the 1874 GW Mining Ord. 


\section{Interests of the quitrent tenant or lessee}

As stated above, a person who wanted to prospect for diamonds on Crown land and on reserved private land had to obtain a prospecting licence. There was no requirement that the consent of the owner of reserved private land had to be obtained for the granting of the prospecting licence. ${ }^{119}$ The owner of reserved private land was referred to as a quitrent tenant and the word "owner" was used in the schedule to the $1874 \mathrm{GW}$ Mining Ordinance to refer to the owner of a claim and not to the owner of the land. ${ }^{120}$

The interests of a quitrent tenant ${ }^{121}$ or lessee were protected in that the certificated miner who applied for a prospecting licence in respect of Crown land or reserved private land, had to take out a bond for the sum of $£ 100$, with two sureties which the Civil Commissioner had to approve in the sum of fifty pounds each for the proper repair of any surface damage done on any land or right occupied by any quitrent tenant or lessee. ${ }^{122}$ If the holder of a prospecting licence found any diamonds while prospecting under the prospecting licence, he was obliged forthwith to report the finding to the Civil Commissioner. ${ }^{123}$ The discoverer of the diamonds was entitled to two claims at the place where such diamonds, gold or silver had been found. ${ }^{124}$

\section{Conversion of the diggings on Vooruitzigt and Dutoitspan to mines}

On 2 June 1874 Richard Southey issued Griqualand West Proclamation 7 of 1874 in terms of the schedule to the $1874 \mathrm{GW}$ Mining Ordinance to convert the diggings known as "Colesberg Kopje" or "De Beer's New Rush" to a mine, to be known as the Kimberley Mine. ${ }^{125}$ The diggings known as "Old De Beer's" or "Kopje No 1"

119 The position was similar under the 1872 GW Prospecting Proclamation, with the exception that unreserved private land was also regulated under the 1872 GW Prospecting Proclamation, but Crown land was excluded.

120 See item 12 of s 1 of the schedule to the 1874 GW Mining Ord.

121 The reference to a quitrent tenant was a reference to the owner of reserved private land.

122 Item 3 of s 7 of the schedule to the $1874 \mathrm{GW}$ Mining Ord. In terms of s 5 of the $1872 \mathrm{GW}$ Prospecting Proclamation the holder of a prospecting licence was only required to provide security in the sum of twenty pounds.

123 Item 4 of s 7 of the schedule to the 1874 GW Mining Ord.

124 Item 5 of s 7 of the schedule to the 1874 GW Mining Ord. The position was similar under s 6 of the 1872 GW Prospecting Proclamation. In terms of s 6 of the 1872 Prospecting Proclamation the discoverer of diamonds on unreserved private land was also entitled to the free grant of two claims at the place where the diamonds had been discovered.

125 In SA Loan Mortgage and Mercantile Agency v Cape of Good Hope Bank and Littlejohn at 163, the Supreme Court of the Cape of Good Hope simply accepted that the land on which the Kimberley Mine was situated, was Crown land. Griqualand West Procl 7 of 2 June 1874 was repealed more than a century later in terms of the Pre-Union Statute Law Revision Act 36 of 1976 (hereafter the Pre-Union Statute Law Act). See Welsh 1976: 227. 
were converted to a mine known as the De Beers Mine. The diggings on the farm Dutoitspan were converted to a mine known as the "Dutoitspan Mine". It is submitted that the de facto status of the diggings known as Colesberg Kopje, Old De Beer's and Dutoitspan, was that they were situated on unreserved private land and therefore not subject to the rules and regulations contained in the schedule to the $1874 \mathrm{GW}$ Mining Ordinance. They were, however, according to the Griqualand West Proclamation 7 of 1874 , which was issued a few days after the commencement of the $1874 \mathrm{GW}$ Mining Ordinance, ${ }^{126}$ de jure proclaimed as public diamond fields. ${ }^{127}$

\section{Griqualand West Ordinance 15 of 1879}

The claimholders of the claims in the Dutoitspan Mine and the Bultfontein Diggings denied that the general rules and regulations contained in the schedule to the 1874 GW Mining Ordinance applied to the Dutoitspan Mine and the Bultfontein Diggings. They accordingly refused to pay the rates levied by the Mining Board for the Dutoitspan Mine and the Inspector of Claims at the Bultfontein Diggings. They also refused to obey any orders from Inspectors. ${ }^{128}$ It is submitted that this view was correct, because the purpose of the rules and regulations of the schedule to the 1874 GW Mining Ordinance was to manage diggings and mines of precious stones on Crown lands and on reserved private land in the Province of Griqualand West and not on unreserved private land. ${ }^{129}$

The Griqualand West Ordinance 15 of 1897 was enacted on 26 November 1879. This Ordinance determined that certain of the rules and regulations contained in the schedule to the $1874 \mathrm{GW}$ Mining Ordinance, relating to Mining Boards and the duties of the Engineer or Surveyor at a mine or the Inspector or Overseer at a digging, were made applicable to the Dutoitspan Mine and the Bultfontein Diggings in so far as they did not conflict with any private rights. ${ }^{130}$

\section{The end of the Southey administration}

The majority of claimholders in Griqualand West were not satisfied with the provisions of the $1874 \mathrm{GW}$ Mining Ordinance. According to Turrell, ${ }^{131}$ their main complaint was that the $1874 \mathrm{GW}$ Mining Ordinance placed significant areas of diggings in the hands of an Engineer or Surveyor, who was responsible to the Government and not the newly elected Mining Boards. The claimholders wanted

126 On 13 May 1874.

127 The Bultfontein diggings were later proclaimed as a diamond mine in terms of Griqualand West Procl 201 of 1881 and Griqualand West Procl 210 of 1882. See Bultfontein Mining Board v Armstrong and the London and South Africa Exploration Co 1890-1891 8 SC 236 at 243.

128 Preamble of Griqualand West Ord 15 of 1879.

129 Preamble of the schedule to the 1874 GW Mining Ord.

130 Section 1 of Griqualand West Ord 15 of 1879. See also Goldschmidt \& Co v Du Toit's Pan Mining Board 18832 HCG 195; Queen v Town 18843 HCG 143.

131 Turrell 1987: 58-59. 
to be able to adjudicate claim disputes and to decide where machinery had to be placed, the rates to be levied and the money to be spent in respect of the mines. The claimholders were not satisfied with the powers of the Engineer, who could prohibit the working of a claim if he was of the view that it was dangerous to do so. There was also a lack of security of tenure. Claimholders of unreserved private land were in particular concerned that landowners of unreserved private land could increase the monthly licence fees payable with regard to the claims. ${ }^{132}$

There were complaints from the claimholders on the farm Vooruitzigt on which the De Beers Mine and the Kimberley Mine were situated. ${ }^{133}$ A syndicate from Port Elizabeth, represented by Alfred Ebden, purchased the farm Vooruitzigt from the De Beer brothers. The new landowners of the farm Vooruitzigt were, however, not satisfied with the monthly rental that they received from claimholders working claims at the De Beers Mine and the Kimberley Mine. The new landowners gave notice that they were going to raise the monthly licence fee to ten pounds. ${ }^{134}$ This occurred while Griqualand West was under the control of Richard Southey. Southey refused to pay the landowner any money collected and, in addition, demanded a refund of all the money paid to the landowners of the farm Vooruitzigt. A long legal battle ensued, which was finally resolved when the landowners of the farm Vooruitzigt agreed to sell the farm to the Government for $£ 1000 .{ }^{135}$ The Griqualand West Ordinance 7 of 1875 was promulgated on 3 August 1875 to sanction the purchase of the farm Vooruitzigt by the Government of the Griqualand West Province. It was recorded in the preamble that it was expedient for public purposes that the Government acquire the farm Vooruitzigt. The terms and conditions for the purchase were set out in a schedule to Griqualand West Ordinance 7 of $1875 .{ }^{136}$

132 It is submitted that this concern was not valid. The monthly licence fees which a landowner of unreserved private land could charge was - in terms of s 8 of the $1872 \mathrm{GW}$ Prospecting Proclamation - fixed at one pound per month. See, also, Rotberg 2002: 80-81.

133 See Turrell 1987: 68. Chilvers 1939: 27-28 describes the conditions at the diamond fields as follows: "Endless disputes arose. With the claims at so many different levels there were ceaseless falls of ground, encroachments and serious accidents. None had anticipated that diamonds would be found so far down. Diggers, syndicates and companies constantly amalgamated, not only to lessen their difficulties but also to be better able to purchase the more expensive equipment now required. The calamitous falls of reef, as the barren soft rock encircling the pipe on all sides is called, ruined many workers at Kimberley, De Beers, Bultfontein and Dutoitspan. Titles, too, seemed insecure, and there was much heart-burning about that. Added to this came the increasingly activity of diamond thieves."

134 This supports the submission that the de facto status of the De Beers Mine and the Kimberley mine was that they were situated on unreserved private land and that the provisions of s 29 of the 1871 GW Diggings Proclamation read with s 8 of the 1872 GW Prospecting Proclamation applied in respect thereof.

135 See, further, Roberts 1984: 122; Turrell 1987: 68-69.

136 It was recorded in s 1 of the schedule to Griqualand West Ord 7 of 1875 that Alfred Ebden ceded, assigned and made over all his rights, title, claims and interest in the farm Vooruitzigt, together with all documents minerals and property of every description in or upon the farm Vooruitzigt. See, also, Newbury 1989: 36-37; Lenzen 1970: 145; Buchanan 1882: par 26. 
In 1875, the majority of claimholders in Griqualand West revolted against the administration of Richard Southey. It was necessary for British troops to be dispatched to Griqualand West to disarm the rebels and to dissolve the rebellion which became known as the "black flag rebellion". ${ }^{137}$ Richard Southey was dismissed in 1875, following the black flag rebellion. Major William Owen Lanyon replaced him as Administrator. ${ }^{138}$ A contributing factor for Southey's dismissal was the declining financial position of the Griqualand West Province. ${ }^{139}$ According to Worger, ${ }^{140}$ Southey had misconstrued his role in the administration of Griqualand West and he implemented the wrong form of diamond mining legislation.

Major Lanyon was instructed to clear the land problems of Griqualand West and to prepare the way for annexation of Griqualand West to the Cape Colony. ${ }^{141}$ Colonel Crossman was appointed to investigate Griqualand West's finances and the grievances that led to the black flag rebellion. ${ }^{142}$ Crossman began his enquiry and in January 1876 he reported on the financial position of Griqualand West. ${ }^{143}$ In May 1876 Crossman furthermore reported on the causes of the black flag rebellion. ${ }^{144}$ One of the recommendations he made was that the restriction of each claimholder to only hold ten claims ${ }^{145}$ should be abolished and that provision should be made for the amalgamation of claims. ${ }^{146}$ Crossman was - according to Worger ${ }^{147}$ - influenced by the submissions of a mining engineer who held the view that the subdivision of the Kimberley Mine into quarters, eighths and sixteenths of claims made profitable working of the mine impossible. The restriction of the number of claims that

137 Davenport 2009: 59. The name of the rebellion was derived from an incident that triggered the rebellion which was described by Roberts 1984: 130 as follows: "At one o'clock in the afternoon of Saturday 15 August 1874, a horse-drawn van paraded solemnly through the streets of Kimberley. Seated in the van was a string band, above which fluttered a flag bearing the inscription 'the earth is the Lord's and the fullness thereof'. But what riveted the attention of most spectators was the pile of diggers' implements, ominously topped by a rifle, stacked at the foot of the flagstaff. The symbolism of the gun covering the mining equipment was unmistakable. Kimberley was being treated to its first whiff of organised revolution." See Roberts (n 1) at 45.

138 Currey, the Government Secretary, was also dismissed. Roberts 1984: 130-140; Turrell 1987: 73.

139 Roberts 1984: 130-140; Turrell 1987: 73.

140 Worger 1987: 29.

141 Major Lanyon presided over Griqualand West until 1878. He was succeeded by Sir Charles Warren in 1879 , who in turn was succeeded by James Rose-Innes in 1880 before Griqualand West was annexed as part of the Cape Colony. Turrell 1987: 73-74.

142 Turrell 1987: 73.

143 "Preliminary Report by Lieutenant-Colonel Crossman on the Financial Condition of Griqualand West" 5 Feb 1876. Crossman found that the structure of the Government's administration at the diamond fields in Griqualand West was too large and expensive for the community of Griqualand West. See Worger 1987: 29-30.

144 "Report of Lieutenant-Colonel Crossman, RE, on the Affairs of Griqualand West" 1 May 1876.

145 Item 18 of s 1 of the schedule to the 1874 Mining Ord.

146 Turrell 1987: 73.

147 Worger 1987: 30. 
each person could hold was abolished in the Griqualand West Ordinance 12 of 20 November 1876.

\section{Third period: The annexation of Griqualand West}

In terms of the Griqualand West Annexation Act 39 of 1877 the entire Province of Griqualand West was annexed as part of the Cape Colony on 15 October 1880. Two of the legislative measures adopted during 1880 were important from a diamond mining perspective. The first was the Griqualand West Ordinance 6 of $1880^{148}$ of 1 June 1880 (hereafter the 1880 GW Fixity of Tenure in Mines Ordinance) that made provision for security of tenure in certain mines and diggings in Griqualand West. The second is the Griqualand West Proclamation 8 of $1880^{149}$ (hereafter the 1880 GW Mining Proclamation) which James Rose-Innes issued on 30 September 1880. Herein, he cancelled the general rules and regulations contained in the schedule to the $1874 \mathrm{GW}$ Mining Ordinance and replaced them with a new set of rules and regulations for the working of mines on Crown land and on reserved private land. ${ }^{150}$

There was uncertainty as to whether the 1880 GW Mining Proclamation repealed and substituted the schedule to the 1874 GW Mining Ordinance. In London and South African Exploration Company Limited v Dutoitspan Mining Board ${ }^{151}$ the High Court of Griqualand West held that

[w]ith regard to the argument as to the effect of Proclamation 8 of 1880 on the schedule to Ordinance 10 of 1874 , so far as that schedule refers to mines on other than Crown lands, it has certainly been always understood in this Court that the Proclamation did not repeal the application of the schedule to such mines. This point, however, it is unnecessary to decide now ...

148 Referred to in s 12 thereof as the "Fixity of Tenure (Mines and Diggings) Ord".

149 Referred to as "Rules and Regulations for the Working of Diggings and Mines on Crown Lands or on Private Properties in which the Precious Stones and Minerals belong to the Crown, in the Province of Griqualand West".

150 Item 1 of s 7 of the $1880 \mathrm{GW}$ Mining Proclamation. The preamble of the $1880 \mathrm{GW}$ Mining Proclamation stated as follows: "Whereas under and by virtue of Ord No. 10 of 1874, it is provided that it shall be lawful for the Governor of the Province of Griqualand West ... to make general Rules and Regulations for the management of Diggings and Mines within the said Province, and such Rules and Regulations from time to time to alter, amend, cancel and re-enact; Now, therefore, I, under and by virtue of the powers in me vested ... do hereby cancel the General Rules and Regulations contained in the Schedule annexed to the aforesaid Ord, No. 10 of 1874 , and I do hereby proclaim, declare and make known that the Rules and Regulations contained in the Schedule hereunto annexed shall, until the same be cancelled, altered, or amended, be the General Rules and Regulations for the working of Diggings and Mines on Crown Lands or on Private Properties in which the Precious Stones and Minerals belong to the Crown in the Province of Griqualand West."

151 At 154 
In Queen $v$ Town ${ }^{152}$ it was argued that the rules and regulations contained in the schedule to the $1874 \mathrm{GW}$ Mining Ordinance continued to apply as they were not cancelled by any act of the Legislature. The High Court of Griqualand West, without giving reasons, confirmed that the rules and regulations in the $1874 \mathrm{GW}$ Mining Ordinance continued to apply. ${ }^{153}$ Four years later, in SA Loan Mortgage and Mercantile Agency $v$ Cape of Good Hope Bank and Littlejohn, ${ }^{154}$ the Supreme Court of the Cape of Good Hope held that the schedule to the 1874 GW Mining Ordinance was indeed repealed by the $1880 \mathrm{GW}$ Mining Proclamation.

\section{The 1880 GW Fixity of Tenure in Mines Ordinance}

The purpose of the $1880 \mathrm{GW}$ Fixity of Tenure in Mines Ordinance was to provide for secure titles for claimholders in mines and diggings on Crown land and on reserved private land. ${ }^{155}$ The $1880 \mathrm{GW}$ Fixity of Tenure in Mines Ordinance provided that holders of claims in any mines or diggings situated on Crown lands could exchange such licences for a perpetual quitrent title which had to be registered in the Deeds Registry of Griqualand West. ${ }^{156}$ The holder of the perpetual quitrent title was entitled to the property in the soil of the claim in perpetuity, including the right to search and take for the holder's own benefit, all precious stones and minerals that could be found therein. In return for the granting of the perpetual quitrent, the holder had to pay, in advance, a perpetual quitrent of six pounds per annum for every claim. ${ }^{157}$ Every claimholder was entitled to the free and undisturbed possession and enjoyment of all claims granted under the 1880 GW Fixity of Tenure in Mines Ordinance, subject only to the provisions of the regulations and by-laws in force at the mine or diggings. ${ }^{158}$

152 At 143 .

153 See, also, Goldschmidt \& Co v Du Toit's Pan Mining Board.

154 At 163.

155 Preamble of the 1880 GW Fixity of Tenure in Mines Ord.

156 Section 3 of the 1880 GW Fixity of Tenure in Mines Ord provided that every mortgage, hypothecation or transfer of any claim in respect of which a perpetual quitrent title was granted, had to be registered in the Deeds Registry in the same manner as required in respect of immovable property.

157 Sections 1 and 2 of the 1880 GW Fixity of Tenure in Mines Ord. The farm Vooruitzigt, on which the Kimberley Mine and the De Beers Mine were situated, became Crown land when it was purchased by the Government of the Province of Griqualand West. In 1903, perpetual quitrent titles were issued to De Beers Consolidated Mines Limited, who was then the holder of all the claims in the two mines. These perpetual quitrent titles were in the form of Certificate of Registered Title T8935/1903 (in respect of the De Beers Mine) and Certificate of Registered Title T8936/1903 (in respect of the Kimberley Mine) registered in the Kimberley Deeds Office. Section 2 of the 1880 GW Fixity of Tenure in Mines Ord provided that every title deed would - as far as applicable - be subject to the same conditions, regulations and charges and would have the same force and effect as an ordinary quitrent title.

158 Section 7 of the 1880 GW Fixity of Tenure in Mines Ord. 
In the case of reserved private land, the holder of a licence in mines or diggings situated on the reserved private land could exchange the licence for a lease for a period not less than three years. ${ }^{159}$ It was expressly stated in the 1880 GW Fixity of Tenure in Mines Ordinance that ${ }^{160}$

[n]othing in this Ordinance contained shall be taken or construed as affecting, or interfering with, the rights of the properties or owners of private properties as aforesaid.

Provision was further made for a Mining Board to allocate to every claimholder sufficient space on the edge of a mine for the erection and maintenance of hauling and other machinery necessary for the working of the claims. The allocation of the additional space was subject to the approval of the Inspector of Mines in respect of the safety of the relevant site. ${ }^{161}$

\section{The 1880 GW Mining Proclamation}

There was no statutory reservation in the $1880 \mathrm{GW}$ Mining Proclamation of the right to diamonds in favour of the British Crown or the Government. This was not necessary as the rules and regulations contained in the schedule to the $1880 \mathrm{GW}$ Mining Proclamation regulated the prospecting for precious stones or minerals and the working of diggings and mines situated on Crown land and on reserved private land and did not apply to unreserved private land. ${ }^{162}$

\section{Rights and obligations of the prospector}

Any person who wanted to prospect or search for diamonds or minerals on Crown land or on reserved private land ${ }^{163}$ could take out a licence at the office of the Civil Commissioner of the relevant division. ${ }^{164}$ The consent of the owner of reserved private land was not required. ${ }^{165}$ A person who wanted to prospect on unreserved

159 Section 8 of the 1880 GW Fixity of Tenure in Mines Ord provided that the lessee was entitled to renew the lease and the rental payable could not exceed six pounds per annum for every claim. The granting of the lease could not interfere with the rights of the owners of the reserved private land. The 1880 GW Fixity of Tenure in Mines Ord referred to the rights of the "proprietors or owners of such private property" and not to a quitrent tenant. In terms of the Griqualand West Registration of Leases (Mines and Diggings) Ord 16 of 1880 dated 22 Sep 1880 (hereafter the $1880 \mathrm{GW}$ Registration of Leases Ord) provision was made for the registration of leases or leasehold titles to claims or portions of claims in mines or diggings. Griqualand West Ord 16 of 1880 was later repealed in terms of the Pre-Union Statute Law Act. See Welsh 1976: 227.

160 Section 10 of the 1880 GW Fixity of Tenure in Mines Ord.

161 Section 9 of the 1880 GW Fixity of Tenure in Mines Ord.

162 See London and SA Exploration Co v Murphy at 329.

163 Referred to in this article as land that was privately owned, but the title of which contained a reservation of the rights to diamonds in favour of the Crown.

164 Item 1 of s 1 of the schedule to the $1880 \mathrm{GW}$ Mining Proclamation.

165 Union Government (Minister of Mines) v Thompson at 421. 
private land had to obtain a prospecting licence in terms of the $1871 \mathrm{GW}$ Diggings Proclamation read with the 1872 Prospecting Proclamation. ${ }^{166}$ The 1880 GW Mining Proclamation did not specifically repeal the provisions of the $1871 \mathrm{GW}$ Diggings Proclamation and the $1872 \mathrm{GW}$ Prospecting Proclamation. ${ }^{167}$ A person who wanted to prospect for diamonds on unreserved private land would have required the consent of the landowner and a prospecting licence. This was confirmed in the prescribed form for a prospecting licence in item 1 of section 1 of the schedule to the $1880 \mathrm{GW}$ Mining Proclamation, wherein it was specifically noted that

[t]his licence does not give any right to prospect on private property where there is no reservation of precious stones or minerals in favour of the Crown without the consent thereto of the owner or owners of such private property ...

A person who wanted to prospect within 500 yards of any other person who was already bona fide prospecting and searching for minerals and diamonds under a prospecting licence, had to obtain the consent of such holder of a prospecting licence. ${ }^{168}$ The holder of a prospecting licence had to be older than sixteen years and in possession of a miner's certificate. ${ }^{169}$ One of the conditions for the issue of a prospecting licence was that the holder had to enter into a bond for the sum of a $£ 100$ with two sureties for the repair of any surface damage done by him on land occupied by any quitrent tenant or lessee. ${ }^{170} \mathrm{~A}$ person who found any diamonds or minerals while prospecting under a prospecting licence, was obliged forthwith to report the discovery to the Civil Commissioner of the relevant division. ${ }^{171}$ The person who discovered the diamonds or minerals under a prospecting licence, was entitled to select ten claims at the place where such precious stones or minerals had been found and received a certificate from the Civil Commissioner to this effect. ${ }^{172}$

166 This requirement was recorded in the prescribed format for a prospecting licence contained in item 1 of s 1 of the schedule to the 1880 GW Mining Proclamation.

167 On the contrary, item 4 of s 4 of the 1880 GW Mining Proclamation made provision for the reservation of depositing areas outside every mine or diggings on Crown land and on reserved private land, which reservation was subject to the rights of the owner of the property and the provisions, so far as the same apply, of ss 23 to 28 inclusive of Griqualand West Procl 71 of 27 Oct 1871.

168 Item 6 of s 1 of the schedule to the $1880 \mathrm{GW}$ Mining Proclamation.

169 Item 12 of s 6 of the schedule to the $1880 \mathrm{GW}$ Mining Proclamation. The position was similar under item 1 of s 1 of the schedule to the 1874 GW Mining Ord.

170 Item 3 of s 1 of the schedule to the $1880 \mathrm{GW}$ Mining Proclamation. The position was similar under item 3 of s 7 of the schedule to the $1874 \mathrm{GW}$ Mining Ord. In the case of unreserved private land, the prospector similarly had to enter into a bond to protect the interests of the landowner, but only for $£ 20$.

171 Item 4 of s 1 of the schedule to the $1880 \mathrm{GW}$ Mining Proclamation.

172 Item 5 of $\mathrm{s} 1$ of the schedule to the $1880 \mathrm{GW}$ Mining Proclamation. Under the $1872 \mathrm{GW}$ Prospecting Proclamation and the 1874 GW Mining Ord the discoverer was entitled to select two claims. 


\section{Rights and obligations of a claimholder}

The Governor of Griqualand West had to appoint an Inspector of Mines for every new digging. ${ }^{173}$ Once a new digging was discovered, the appointed Inspector of Mines had to visit the digging for purposes of allotting and registering claims. ${ }^{174}$ The Inspector had to measure and number all the claims at the digging and prepare a plan after which he had to give notice of a specific date and time when claims would be allocated to certificated miners. The certificated miners had to attend in person on the specific date to have the claims registered in their names. ${ }^{175}$

At a new digging, each claimholder was - with the exception of the discoverer of the diggings - only entitled to one claim. No claimholder could transfer his claims during the first three months of the proclamation of the digging. ${ }^{176}$ Any claim that remained unregistered or unworked for a period of seven days, which excluded a Sunday or a public holiday, had to be declared abandoned by the Inspector unless he had issued a certificate of reservation. ${ }^{177}$ Where a claimholder failed to comply within seven days with an instruction from the Inspector to perform certain specific work in respect of his claim, the Inspector similarly had to declare the claim as abandoned. ${ }^{178}$ The number of abandoned claims at a digging had to be posted at the digging or at a conspicuous place at the office of the Inspector of Mines. ${ }^{179}$ Any certificated miner could apply to obtain abandoned claims and if more than one applicant applied, the claim was sold through a public auction. ${ }^{180}$ Otherwise, a claimholder could abandon a claim by giving written notice of his intention to abandon the claim to the Inspector of Mines. ${ }^{181}$

173 A new digging was defined in item 1 of $\mathrm{s} 1$ of the schedule to the $1880 \mathrm{GW}$ Mining Proclamation as a digging which was proclaimed a digging after the proclamation of the $1880 \mathrm{GW}$ Mining Proclamation.

174 Item 2 of s 2 of the schedule to the 1880 GW Mining Proclamation.

175 Item 3 of s 2 of the schedule to the $1880 \mathrm{GW}$ Mining Proclamation. Item 5 of s 2 of the schedule to the $1880 \mathrm{GW}$ Mining Proclamation provided that once two-thirds of the claims in a digging had been allocated and registered, the Inspector had to define an area outside the claims which was reserved for mining purposes. If the digging was situated on Crown land, the Inspector had to fix the site of the camp or township and issue regulations for the cutting of firewood, grazing of cattle and if necessary, the sinking of wells for water.

176 Item 8 of s 2 of the schedule to the 1880 GW Mining Proclamation.

177 A certificate of reservation could be obtained in the case of sickness, a necessary absence or other sufficient cause. A fee of one shilling was payable for each day that the certificate was issued, but excluding for Sundays and public holidays. A certificate of reservation could not be issued for a period longer than twenty working days. Seenitem 13 of s 2 of the schedule to the $1880 \mathrm{GW}$ Mining Proclamation.

178 Item 9 of s 2 of the schedule to the 1880 GW Mining Proclamation.

179 Item 10 of s 2 of the schedule to the $1880 \mathrm{GW}$ Mining Proclamation.

180 Item 11 of s 2 of the schedule to the $1880 \mathrm{GW}$ Mining Proclamation.

181 Item 12 of s 2 of the schedule to the 1880 GW Mining Proclamation. See London and SA Exploration Co v Bultfontein Mining Board at 220. 
Only persons older than sixteen years and who had received a miner's certificate ${ }^{182}$ were entitled to be registered as or to be a claimholder in any new diggings. Every claimholder was entitled to the free an undisturbed possession of any claim or claims registered in his name, but subject to a general reservation of seven feet and six inches on one side of each claim for roadways. ${ }^{183}$

If there were at any time less than twelve registered claimholders at a new digging, the digging could be closed by proclamation after at least one month's notice had been given. The Governor could also - if a digging ceased to be worked in a bona fide manner - declare the digging to be closed. ${ }^{184}$ Unless a new digging was proclaimed to be closed, every new digging had to be proclaimed as an established digging after the expiry of six months from its initial proclamation as a new digging. ${ }^{185}$ The Governor could by proclamation proclaim any digging to be a mine. ${ }^{186} \mathrm{He}$ also had to appoint a Registrar for each proclaimed mine. The Registrar of a mine had to keep a register of the claims and claimholders in the mines. This did not apply to mines in respect of which the provisions of the $1880 \mathrm{GW}$ Fixity of Tenure in Mines Ordinance applied. The Registrar further had to perform the same functions as an Inspector of Mines with regard to registration at a digging. ${ }^{187}$ Mines were under the control of a Mining Board, which consisted of twelve persons elected by the claimholders. ${ }^{188}$ Each Mining Board had to draft by-laws for the management of the relevant mine for which it was elected. ${ }^{189}$

182 A miner had to obtain a certificate from the Resident Magistrate of the relevant district. The cost to obtain such a certificate was one pound for a period of twelve months, ten shillings for six months, or five shillings for three months. Item 14 of s 2 of the schedule to the $1880 \mathrm{GW}$ Mining Proclamation.

183 Item 15 of s 6 of the schedule to the $1880 \mathrm{GW}$ Mining Proclamation provided that in the event that a larger quantity of ground was required for public purposes or for digging or mine, such ground could be taken by the Governor subject to the payment of compensation to the owner of the claim.

184 Item 17 of s 2 of the schedule to the 1880 GW Mining Proclamation.

185 Item 1 of s 3 of the schedule to the $1880 \mathrm{GW}$ Mining Proclamation. Where there were more than fifty registered claimholders at a new digging, item 6 of s 2 of the schedule to the $1880 \mathrm{GW}$ Mining Proclamation provided that the claimholders were entitled to apply to the Government to elect a Diggers' Committee comprising of not less than five and not more than nine members. The Diggers' Committee had to make by-laws for the relevant diggings and the by-laws became effective once they had been approved by the Government and published in the Gazette. Provision was also made in item 2 of s 3 of the schedule to the $1880 \mathrm{GW}$ Mining Proclamation for the establishment of Diggers' Committees at established diggings where there were more than fifty registered claimholders and for the adoption of by-laws. Item 5 of s 3 of the schedule to the 1880 GW Mining Proclamation provided that in the absence of elected Diggers' Committees, the Inspector of Mines for a specific digging could make by-laws for the digging, which became effective once they had been approved by the Governor and published in the $G G$.

186 Item 1 of s 4 of the schedule to the 1880 GW Mining Proclamation.

187 Item 3 of s 4 of the schedule to the $1880 \mathrm{GW}$ Mining Proclamation.

188 Items $1-5$ of s 5 of the schedule to the $1880 \mathrm{GW}$ Mining Proclamation.

189 Item 10 of s 5 of the schedule to the $1880 \mathrm{GW}$ Mining Proclamation. 
Provision was also made for a depositing area outside every mine or digging on Crown land and on reserved private land. The reservation of a depositing area on reserved private land was expressly stated to be subject to the rights of the owner of such land and also to the provisions of sections 23 to 28 of the $1871 \mathrm{GW}$ Diggings Proclamation in so far as they continued to apply. ${ }^{190}$ The Governor therefore had to attempt to reach an agreement with the owner of the reserved private land on the terms on which the depositing areas would be used. However, if the owner did not agree to the terms, the Governor could simply cause the depositing areas to be reserved subject to the payment of reasonable compensation to the owner of the reserved private land. ${ }^{191}$ The depositing area had to be as near as convenient to the mine and the Inspector of Mines had to divide it into zones or belts which ran parallel with the mine. ${ }^{192}$

Every claimholder was entitled to use an area which in total did not exceed one acre for each full claim held of the depositing area as a depositing floor. ${ }^{193}$ The claimholder was entitled to sink wells within the depositing floor, which might be necessary for the purposes of working claims in the relevant mine or digging. In the case of Crown land, the consent of the Governor was required and in the case of reserved private land, the consent of the landowner was required for the sinking of wells. ${ }^{194}$ Every claimholder of a mine situated on Crown land had to pay a monthly rental for the use of a depositing floor. The rental was payable for as long as the claim was registered in the name of the claimholder, irrespective of whether the depositing floor was being used. The rental was determined with reference to the position of the depositing floor and its distance from the mine. ${ }^{195}$

190 Item 4 of s 4 of the schedule to the 1880 GW Mining Proclamation. Sections 23-28 of the 1871 GW Diggings Proclamation provided that the High Commissioner could - in the case of reserved private land - agree with the landowner on the terms on which the diamond diggings situated on the land could be worked. If the landowner did not agree to the terms, the High Commissioner could simply - after giving notice to the landowner - enter the land or cause the land to be entered subject to the payment of reasonable compensation for all injury done to the surface and soil of the land.

191 Item 4 of s 4 of the schedule to the $1880 \mathrm{GW}$ Mining Proclamation read with s 26 of the $1871 \mathrm{GW}$ Diggings Proclamation.

192 Item 5 of s 4 of the schedule to the $1880 \mathrm{GW}$ Mining Proclamation.

193 Item 11 of s 4 of the schedule to the $1880 \mathrm{GW}$ Mining Proclamation provided that the health and safety at depositing floors were under the control of the Inspector of each mine, but it was regulated by the by-laws adopted by the relevant Mining Board which had to be approved by the Governor.

194 Item 6 of s 4 of the schedule to the 1880 GW Mining Proclamation.

195 The monthly rental could not exceed the amount of one pound per acre unless the claimholder specifically agreed thereto. See item 8 of s 4 of the schedule to the $1880 \mathrm{GW}$ Mining Proclamation. Claims in mines or diggings within the Province of Griqualand West had to be registered by the Registrar of Deeds in terms of the 1880 GW Registration of Leases Ord. Cessions, assignments, transfers, surrenders, mortgages and hypothecations of claims or cessions had to be registered in terms of s 1 of the $1880 \mathrm{GW}$ Registration of Leases Ord. Section 7 of the $1880 \mathrm{GW}$ Registration of Leases Ord provided that a lease did not cease or terminate in the case of insolvency of the person entitled to the lease. 
Although there was no requirement that the consent of the landowner of reserved private land be obtained for the grant of a prospecting licence, ${ }^{196}$ no person was entitled to prospect within 200 yards of any house or building occupied or upon land under cultivation without the consent of the owner or occupier of the relevant land. ${ }^{197}$

\section{Conclusion}

In this article, the diamond mining legislation that was enacted in Griqualand West during the period 1871 until its annexation as part of the Cape Colony in 1880 was discussed. During this period, Griqualand West was under the control of three different administrations, each of which enacted different diamond mining legislation. There were at least four factors that influenced the development of diamond mining legislation in Griqualand West during the period 1871 to 1880.

In the first instance - and perhaps the most important factor - was the form of land tenure. From the discussion of the diamond mining legislation which each of the three administrations enacted, it appears that the question as to who was entitled to prospect or search for diamonds or to work claims at the diamond fields depended on the specific form of land tenure, and in effect the common law holder of the rights to diamonds.

The second factor is the governing authority. In all instances where there was a change in the governing authority, one of the very first pieces of legislation that was amended and/or repealed, was the diamond mining legislation. Since the very early years following the proclamation of Griqualand West as a British territory in 1871, the relevant Government had played a regulatory role in respect of diamond mining.

The third factor which contributed to the development of diamond mining legislation in Griqualand West was the habitat or the source of the diamonds, in other words whether the diamonds occurred in alluvial form or in a kimberlite pipe. The 1874 GW Mining Ordinance which was enacted in Griqualand West was the first diamond mining legislation in which the working of alluvial diggings and the mining of diamonds were regulated separately.

The fourth factor which impacted on the development of diamond mining legislation is the developments in diamond mining technology and in particular with reference to the early years following the discovery of the first diamonds the method of diamond mining. The early diamond mining legislation had to make provision for depositing floors or sites where mined material could be deposited and left to be pulverised by the sun because of the imperfections in the early primitive diamond mining methods. A further change in diamond mining legislation brought about by the method of diamond mining was the removal of the statutory prohibition

196 The position was similar under the 1874 GW Mining Ord.

197 Item 7 of s 1 of the schedule to the $1880 \mathrm{GW}$ Mining Proclamation and recorded in the prescribed format for a prospecting licence in $\mathrm{s} 1$ of the schedule to the $1880 \mathrm{GW}$ Mining Proclamation. 
on the number of claims that could be held and allowing claims to be amalgamated. This was in particular necessary in Griqualand West where diggers who owned individual claims removed the soil within each claim at their own time, resulting in ground slides between adjoining claims.

After the annexation of Griqualand West as part of the Cape Colony in 1880, new challenges emerged. Not only were the claims in the four large diamond mines amalgamated, but the diamond mining legislation was also consolidated.

\section{BIBLIOGRAPHY}

Beet, G \& Terpend, TL (1917) The Romance and Reality of the Vaal Diamond Diggings (Kimberley)

Boyle, F (1873) To the Cape for Diamonds: A Story of Digging Experiences in South Africa (London)

Buchanan (1882) "Memorandum on the early legislation in diamond matters" in the Cape of Good Hope Report of the Commissioners Appointed to Inquire into and Report upon the Working and Management of the Diamond Fields or Griqualand West 1881-1882 (Cape Town)

Chilvers, HW (1939) The Story of De Beers (London)

Dale, MO (1979) An Historical and Comparative Study of the Concept and Acquisition of Mineral Rights (LLD-thesis, University of South Africa)

Davenport, J (2009) Colonial Mining Policy of the Cape of Good Hope: An Examination of the Evolution of Mining Legislation in the Cape Colony, 1853-1910 (MA-dissertation, University of Cape Town)

Davenport, J (2013) Digging Deep: A History of Mining in South Africa (Johannesburg)

Doughty, O (1963) Early Diamond Days: The Opening of the Diamond Fields of South Africa (London)

Herbert, I (1972) The Diamond Diggers: South Africa 1866 to the 1970s (London)

Hornsby, AH (1874) The South African Diamond Fields: A Practical Matter-of-Fact Account (Chicago)

Lenzen, G (1970) The History of Diamond Production and Diamond Trade (London)

Machens, EW (2009) Platinum, Gold and Diamonds: The Adventure of Hans Merensky's Discoveries (Pretoria)

Marquard, L (1955) The Story of South Africa (London)

McNish, JT (1968) The Road to El Dorado (Cape Town)

Meredith, M (2007) Diamonds, Gold and War: The Making of South Africa (Jeppestown)

Millin, SG (1933) Rhodes (London)

Newbury, C (1989) The Diamond Ring Business, Politics and Precious Stones in South Africa 1867-1947 (Oxford)

"Preliminary Report by Lieutenant-Colonel Crossman on the Financial Condition of Griqualand West" 5 February 1876

"Report of Lieutenant-Colonel Crossman, RE, on the Affairs of Griqualand West" 1 May 1876 


\section{ANNEKE HIGGS}

Roberts, B (1972) The Diamond Magnates (London)

Roberts, B (1984) Kimberley Turbulent City (Cape Town)

Rotberg, RI (2002) The Founder: Cecil Rhodes and The Pursuit of Power (Johannesburg)

Simons, PB (2004) Cullinan Diamonds: Dreams and Discoveries (Vlaeberg)

Turrell, RV (1987) Capital and Labour on the Kimberley Diamond Fields 1871-1890 (Melbourne)

Welsh, RS (1976) “Mining law” Annual Survey of South African Law: 227-232

Williams, GF (1905) The Diamond Mines of South Africa vol 1 (New York)

Worger, WH (1987) South Africa's City of Diamonds Mine Workers and Monopoly Capitalism in Kimberley 1867-1895 (Craighall)

\section{Legislation}

Amendment of Land Court Ordinance 13 of 1876

Cape GN 35 of 5 April 1875

Cape GN 33 of 10 January 1881

Griqualand West Annexation Act 39 of 1877

Griqualand West Ord 1 of 1874

Griqualand West Ord 3 of 1874 (1874 GW Crown Land Ordinance)

Griqualand West Ord 5 of 1874

Griqualand West Ord 10 of 1874 (1874 GW Mining Ordinance)

Griqualand West Ord 3 of 1875 (1875 GW Land Court Ordinance)

Griqualand West Ord 7 of 1875

Griqualand West Ord 12 of 1876

Griqualand West Ord 15 of 1879

Griqualand West Ord 6 of 1880 (1880 GW Fixity of Tenure in Mines Ordinance)

Griqualand West Ord 16 of 1880 (1880 GW Registration of Leases Ordinance)

Griqualand West Ord 21 of 1880

Griqualand West Procl 68 of 27 October 1871

Griqualand West Procl 69 of 27 October 1871

Griqualand West Procl 70 of 27 October 1871

Griqualand West Procl 71 of 27 October 1871 (1871 GW Diggings Proclamation)

Griqualand West Procl 72 of 27 October 1871 (1871 GW Quieting Proclamation).

Griqualand West Procl 73 of 27 October 1871

Griqualand West Procl 30 of 17 November 1871

Griqualand West Procl 31 of 17 November 1871

Griqualand West Procl 32 of 17 November 1871

Griqualand West Procl 33 of 28 November 1871

Griqualand West Procl 34 of 28 November 1871

Griqualand West Procl 35 of 8 December 1871 


\section{THE HISTORICAL DEVELOPMENT OF DIAMOND MINING LEGISLATION}

Griqualand West Procl 39 of 10 January 1872

Griqualand West Procl 47 of 23 July 1872

Griqualand West Procl 53 of 4 September 1872

Griqualand West Procl 59 of 7 November 1872 (1872 GW Prospecting Proclamation)

Griqualand West Procl 75 of 30 November 1872

Griqualand West Procl 76 of 30 November 1872

Griqualand West Procl 2 of 31 January 1873

Griqualand West Procl 5 of 26 February 1873

Griqualand West Procl 21 of 5 July 1873

Griqualand West Procl 22 of 5 July 1873

Griqualand West Procl 6 of 4 May 1874

Griqualand West Procl 7 of 2 June 1874

Griqualand West Procl 8 of 30 September 1880 (1880 GW Mining Proclamation)

Griqualand West Procl 201 of 1881

Griqualand West Procl 210 of 1882

Ord to Establish a Court to Adjudicate on Claims to Land in the Province of Griqualand West of 1875 (1875 GW Land Court Ordinance)

Pre-Union Statute Law Revision Act 36 of 1976 (Pre-Union Statute Law Act)

Precious Stones and Minerals Mining Act 19 of 1883

Sir John Cradock's Proclamation on Conversion of Loan Places to Quitrent Tenure 6 of 1813 (Cradock Proclamation)

\section{Case law}

Bank of Africa v Kimberley Mining Board 18843 HCG 371 (Bank of Africa case)

Beaconsfield Municipality v London and SA Exploration Co Ltd 18843 HCG 183

Botha $v$ Minister of Lands 1965 (1) SA 728 (A)

Bultfontein Mining Board v Armstrong 1890-1892 6 HCG 57

Bultfontein Mining Board v Armstrong and the London and South Africa Exploration Co 189018918 SC 236

Carter v Van Niekerk and Union Government (Minister of Lands) 1910-1917 GWLD 445

Goldschmidt \& Co v Du Toit's Pan Mining Board 18832 HCG 195

Kimberley Divisional Council v London and SA Exploration Co Ltd 1885-19062 Buch 84

London and SA Exploration Co v Bultfontein Mining Board 1888-1889 6 SC 201

London and SA Exploration Co Ltd v Dutoitspan Mining Board 18832 HCG 154

London and SA Exploration Co Ltd v Trustees of Isaacs \& Co 18843 HCG 174

London and SA Exploration Co Ltd v Kimberley Divisional Council 18843 HCG 125

London and SA Exploration Co v Murphy 1886-1887 4 HCG 322 


\section{ANNEKE HIGGS}

Minister of Mineral Resources of the Republic of South Africa $v$ Sishen Iron Ore Company (Pty) Ltd 2013 (4) SA 461 (SCA)

Murtha v Von Beek 1880-1884 1 Buch AC 121

Queen v Town 18843 HCG 143

Reed v De Beers Consolidated Mines Limited 91892 Juta SC 33

SA Loan Mortgage and Mercantile Agency v Cape of Good Hope Bank and Littlejohn 1888-1889 $6 \mathrm{SC} 163$

Union Government (Minister of Mines) v Thompson 1919 AD 404

Van Niekerk and Union Government (Minister of Lands) v Carter 1917 AD 359

Webb v Giddy 18783 App Cas 908 